\title{
Non-susceptible landslide areas in Italy and in the Mediterranean region
}

\author{
I. Marchesini ${ }^{1}$, F. Ardizzone ${ }^{1}$, M. Alvioli ${ }^{1}$, M. Rossi ${ }^{1,2}$, and F. Guzzetti ${ }^{1}$ \\ ${ }^{1}$ Consiglio Nazionale delle Ricerche, Istituto di Ricerca per la Protezione Idrogeologica, via Madonna Alta 126, \\ 06128 Perugia, Italy \\ ${ }^{2}$ Università degli Studi di Perugia, Dipartimento di Scienze della Terra, Piazza Università, 1, \\ 06123 Perugia, Italy
}

Correspondence to: I. Marchesini (ivan.marchesini@irpi.cnr.it)

Received: 9 January 2014 - Published in Nat. Hazards Earth Syst. Sci. Discuss.: 24 April 2014

Revised: - - Accepted: 27 July 2014 - Published: 27 August 2014

\begin{abstract}
We used landslide information for 13 study areas in Italy and morphometric information obtained from the 3arcseconds shuttle radar topography mission digital elevation model (SRTM DEM) to determine areas where landslide susceptibility is expected to be negligible in Italy and in the landmasses surrounding the Mediterranean Sea. The morphometric information consisted of the local terrain slope which was computed in a square $3 \times 3$-cell moving window, and in the regional relative relief computed in a circular $15 \times 15$-cell moving window. We tested three different models to classify the "non-susceptible" landslide areas, including a linear model (LNR), a quantile linear model (QLR), and a quantile, non-linear model (QNL). We tested the performance of the three models using independent landslide information presented by the Italian Landslide Inventory (Inventario Fenomeni Franosi in Italia - IFFI). Best results were obtained using the QNL model. The corresponding zonation of non-susceptible landslide areas was intersected in a geographic information system (GIS) with geographical census data for Italy. The result determined that $57.5 \%$ of the population of Italy (in 2001) was located in areas where landslide susceptibility is expected to be negligible. We applied the QNL model to the landmasses surrounding the Mediterranean Sea, and we tested the synoptic non-susceptibility zonation using independent landslide information for three study areas in Spain. Results showed that the QNL model was capable of determining where landslide susceptibility is
\end{abstract}

expected to be negligible in the validation areas in Spain. We expect our results to be applicable in similar study areas, facilitating the identification of non-susceptible landslide areas, at the synoptic scale.

\section{Introduction}

Landslide susceptibility is the likelihood of a landslide occurring in a given area (Brabb, 1984). It is an estimate of where landslides are expected to occur on the basis of local geoenvironmental conditions (Guzzetti, 2005). Over the past three decades, research scientists, and planning and environmental organizations, have attempted - with various degrees of success - to assess landslide susceptibility at different geographical scales, and to produce maps portraying its spatial distribution (i.e. landslide susceptibility zonation). A large number of methods and techniques were proposed and tested to ascertain landslide susceptibility, including geomorphological mapping, analysis of inventories, heuristic zoning, statistical and probabilistic methods, and process-based (conceptual) models, using a variety of mapping units, including grid cells, terrain units, unique condition units, slope units, geo-hydrological units, topographic units, and geographical (administrative) units (Guzzetti et al., 1999; Guzzetti, 2005). In recent years, a few attempts were made to determine landslide susceptibility at the continental and even at the global 
scale (Nadim et al., 2006; Hong et al., 2007a, b; Kirschbaum et al., 2009; Van Den Eeckhaut et al., 2012; Farahmand and AghaKouchak, 2013; Günther et al., 2013, 2014). Due to the generalized lack of accurate and complete landslide information (Guzzetti et al., 2012), these synoptic scale attempts have either not used information on the location and extent of the landslides, or have used unsystematic point landslide information to ascertain landslide susceptibility (Günther et al., 2013, 2014).

Regardless of the mapping unit and the method used, all the proposed attempts focus - directly or indirectly, and explicitly or implicitly - on the identification of the areas where susceptibility is expected to be largest, i.e. on the definition of the potentially most hazardous landslide areas (Chung and Fabbri, 1999; Guzzetti et al., 1999, 2005a). Little effort was made to determine where landslides are not expected (Chung and Fabbri, 2003; Fabbri et al., 2003), i.e. where landslide susceptibility is null, or negligible (Godt et al., 2012). A notable exception is the work of Godt et al. (2012), which proposes a synoptic map for the conterminous United States showing areas with negligible landslide susceptibility i.e. areas where landslides are not expected.

In this work, we propose a new model to determine "nonsusceptible" landslide areas, in Italy and in the Mediterranean region, at the synoptic scale. Non-susceptible areas are those areas where susceptibility to landslides is expected to be "negligible". Our work is conceptually and operationally different to the determination of landslide susceptibility, using either heuristic (ruled-based) or statistical approaches (Guzzetti, 2005).

The paper is organized as follows: after a description of the available topographic and landslide data (Sect. 2), we present three non-susceptibility landslide models for Italy (Sect. 3), and we test the three models against independent landslide information. We adopt the best model for zoning non-susceptible landslide areas in Italy (Sect. 4). We use the model to measure the size of the population of Italy in nonsusceptible areas (Sect. 5.1), and we extend the model to the landmasses surrounding the Mediterranean Sea (Sect. 5.2). We then discuss our findings, in view of their general and specific impact (Sect. 6), and we conclude by summarizing the main results obtained (Sect. 7).

\section{Available data}

For our work, we used a global terrain elevation data set and landslide information in Italy and Spain.

\subsection{Terrain information}

The terrain elevation data consisted of the shuttle radar topography mission (SRTM) version 2.1 digital elevation model (DEM), available from http://dds.cr.usgs.gov/srtm/ (Jarvis et al., 2008; Farr et al., 2007; Verdin et al., 2007).
In the DEM, elevation data have a 3 arcsecond ground spacing in longitude and latitude, approximately $92 \mathrm{~m} \times 92 \mathrm{~m}$ at the equator and $92 \mathrm{~m} \times 69 \mathrm{~m}$ at the latitudes of our study areas. The DEM is distributed in $5^{\circ} \times 5^{\circ}$ tiles, in the WGS 84 (EPSG 4326) longitude-latitude Coordinate Reference System (CRS). Following Godt et al. (2012), we maintained the DEM in the original geographical (longitude, latitude) CRS, and we assembled eight tiles to cover the Italian territory, and 40 tiles to cover the Mediterranean region (Fig. 1).

\subsection{Landslide information}

We used different sources of landslide information, in Italy and Spain. In Italy, we exploited a collection of 13 regional landslide inventories and the national Italian Landslide Inventory (Inventario Fenomeni Franosi in Italia IFFI) (Trigila et al., 2010). In Spain, we used three geomorphological landslide inventories prepared by the Instituto Geológico y Minero de España (IGME). The various sources of landslide information were used differently. We exploited the 13 regional inventories to prepare three non-susceptibility models for Italy, and the IFFI national inventory (Trigila et al., 2010) to validate the non-susceptibility models. We used the landslide information in Spain to evaluate a zonation of areas non-susceptible to landslides for the Mediterranean Region (Fig. 1).

\subsubsection{Regional landslide inventory maps}

For Italy, we obtained landslide information from 13 regional geomorphological (Antonini et al., 1993, 2000; Cardinali et al., 2001; Antonini et al., 2002), event (Cardinali et al., 2000; Guzzetti et al., 2004; Ardizzone et al., 2007, 2012), and multi-temporal (Guzzetti et al., 2005a, 2006; Galli et al., 2008; Guzzetti et al., 2009) inventory maps (Fig. 2, Table 1). The landslide maps were prepared over the period from 1993 to 2013 by the same general team of geomorphologists experienced in landslide mapping (http://geomorphology.irpi.cnr.it).

The individual inventories covered areas ranging from 19 to $9366 \mathrm{~km}^{2}$, and were prepared through the visual interpretation of stereoscopic aerial photographs flown at scales ranging from $1: 5000$ to $1: 75000$. These were aided by field checks carried out primarily after meteorological landslide triggering events (Cardinali et al., 2000; Guzzetti et al., 2004; Ardizzone et al., 2012), or to validate locally the geomorphological (Antonini et al., 1993, 2000, 2002; Cardinali et al., 2001) and the multi-temporal (Guzzetti et al., 2005a, 2006; Galli et al., 2008; Guzzetti et al., 2009) inventories. The landslide information obtained from the aerial photographs or in the field was transferred, visually or using semi-automatic methods, on topographic base maps at scales ranging from $1: 10000$ to $1: 25000$. The base maps were in different CRSs, including the Gauss Boaga West (EPSG 3003) and East (EPSG 3004) CRSs, and the Zone 32 (EPSG 23032) and 


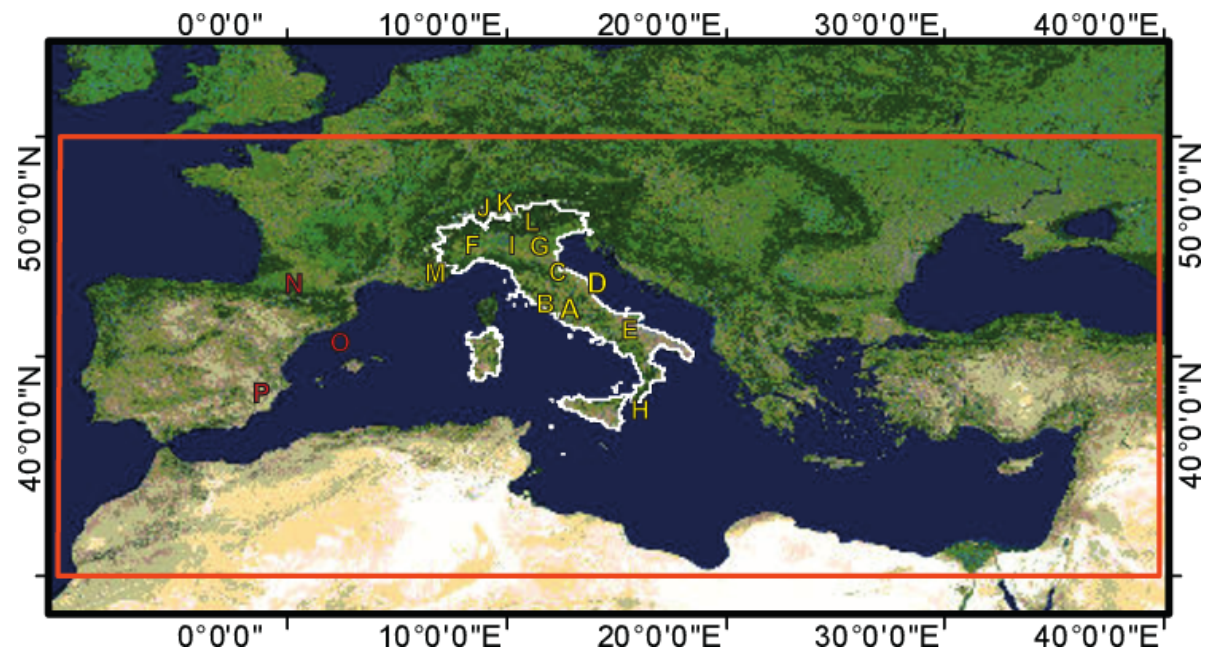

Figure 1. Location of the study areas. White line shows Italy, where the non-susceptibility landslide model was calibrated and tested. Red box shows the area surrounding the Mediterranean Sea, where the model was applied. Yellow capital letters (A)-(M) show locations of the regional landslide inventories used to calibrate the non-susceptibility model, and red capital letters $(\mathrm{N})-(\mathrm{P})$ show other locations used to validate the non-susceptibility model. Legend: (A) Umbria region, central Italy. (B) Collazzone, Umbria, central Italy. (C) Upper Tiber River basin, central Italy. (D) Marche, central Italy. (E) Basento and Cavone catchments, southern Italy. (F) Staffora catchment, Lombardia, northern Italy. (G) Setta catchment, Emilia-Romagna, northern Italy. (H) Messina, Sicily, southern Italy. (I) Lunigiana, Toscana, northern Italy. (J) Lecco, Lombardia, northern Italy. (K) Valcamonica, Lombardia, northern Italy. (L) Valseriana, Lombardia, northern Italy. (M) Imperia, Liguria, northern Italy. (N) Pyrenees, northern Spain (O) Murcia, southern Spain. (P) Tramuntana range, Majorca, Spain. See Table 1 for details on the study areas and the landslide inventories, and for references.

Zone 33 (EPSG 23033) UTM-ED50 CRSs. The landslide information was then digitized, and stored in dedicated GIS databases, where polygons show the individual landslides, in vector format. For our analyses, we first transformed the landslide information from their original CRS to the WGS84 (EPSG 4326) longitude-latitude CRS, for consistency with the CRS used by the SRTM DEM. Next, we transformed the vector landslide information to a raster (grid) format. In the original inventories, for the deep-seated failures of the slide and/or complex types, the landslide source (depletion) area was mapped separately from the depositional area. The separation was not made for the shallow failures. When the landslide information was transformed to the grid format, the internal subdivisions were not maintained, and the resulting grid maps show the presence of landslides, encompassing the source and the deposition areas.

Collectively, the 13 inventories are representative of most of the physiographical provinces in Italy (Guzzetti and Reichenbach, 1994) in which landslides are abundant (Fig. 2). Figure ?? summarizes the distributions of terrain elevation and slope angle in the 13 study areas, and Table 1 lists the main characteristics of the landslide inventory maps. The 13 landslide maps cover $26992 \mathrm{~km}^{2}$ ( $8.9 \%$ of Italy) and collectively show 93538 landslides, for a total landslide area of $2726 \mathrm{~km}^{2}$ (10.1\% of the total mapped areas). The average landslide density for the 13 inventories is 3.5 landslides per square kilometre. The inventories primarily show rotational and translational slides, earth flows, complex, and compound movements (Cruden and Varnes, 1996). In some of the inventories, soil slips, debris flows, rock falls, and topples are shown.

We maintain that the collection of the 13 inventories represents a high-quality (Guzzetti et al., 2012) and consistent landslide data set to investigate terrain characteristics prone (or not prone) to landslides, in Italy. We base the statement on the accuracy and completeness of the single inventories, and on the fact that the inventories were prepared by the same team of geomorphologists. This team has adopted the same (or very similar) photo-interpretation criteria, and has used the same (or comparable) tools to prepare the landslide maps, including the type of stereoscopes and the methods used to transfer the landslide information from the aerial photographs to the digital landslide databases. This has limited the uncertainty associated to the landslide information obtained from the inventory maps.

We exploited the collection of the 13 regional geomorphological, event, and multi-temporal inventory maps to prepare three non-susceptibility landslide models for Italy (see Sect. 3).

\subsubsection{Italian national landslide inventory}

The IFFI is the result of a collective effort performed by the national, regional, and provincial geological surveys to map landslides in Italy (Trigila et al., 2010). The national inventory contains information on 482272 landslides, for a total landslide area of $20500 \mathrm{~km}^{2}$ (6.8\% of Italy), with an average 


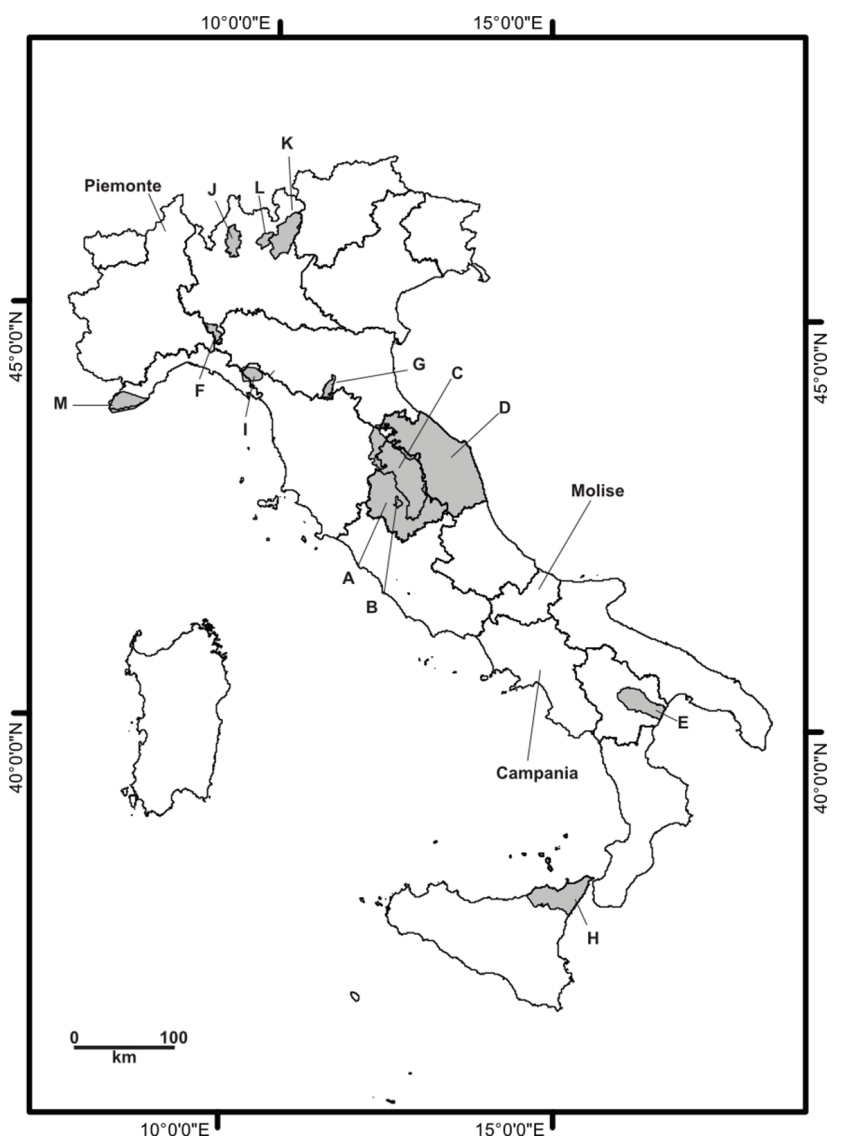

Figure 2. Location and extent of the 13 regional landslide inventory maps in Italy used in this study. Legend: (A) Umbria region, central Italy. (B) Collazzone, Umbria, central Italy. (C) Upper Tiber River basin, central Italy. (D) Marche, central Italy. (E) Basento and Cavone catchments, southern Italy. (F) Staffora catchment, Lombardia, northern Italy. (G) Setta catchment, Emilia-Romagna, northern Italy. (H) Messina, Sicily, southern Italy. (I) Lunigiana, Toscana, northern Italy. (J) Lecco, Lombardia, northern Italy. (K) Valcamonica, Lombardia, northern Italy. (L) Valseriana, Lombardia, northern Italy. (M) Imperia, Liguria, northern Italy. See Table 1 for details on the study areas and the landslide inventories, and for references.

density of 1.6 landslides per square kilometre. The landslide information shown in the IFFI database was obtained from various sources and using different methods, including the interpretation of aerial photographs, the analysis of historical documents and archives, the analysis of pre-existing geological and geomorphological maps, field surveys, and combinations of these sources and methods (Trigila et al., 2010). The landslide types considered in the inventory are falls and topples, complex movements, slow (earth) flows, rapid flows, translation and rotational slides, and lateral spreads. The national inventory also shows areas affected by diffused landslides, failures of undefined type, and sinkholes. Due to the complexity of the inventory, and to the methods used to compile and harmonize the landslide information, the IFFI database exhibits geographical inconsistency and lacks homogeneity (Trigila et al., 2010).

The IFFI database was not available to us in vector format. For our research, we used the landslide information that was published through the web map service (WMS) (De La Beaujardiere, 2004) and made available by the Istituto Superiore per la Protezione e la Ricerca Ambientale - ISPRA. To obtain the landslide information, we performed multiple "GetMap" requests using the WMS. As a compromize between geographical accuracy of the landslide information and time required for the requests, we set a ground resolution equivalent to $5 \mathrm{~m} \times 5 \mathrm{~m}$ for the landslide information. We only retrieved information on landslides shown as polygons in the IFFI geographical database, discarding landslides represented by points and linear features. We also discarded areas classified as "affected by diffused landslides" in the IFFI data set. Each request resulted in a single portable network graphics (PNG) file. We assembled all the PNG files in a single raster layer where the landslide types were separated on the basis of the colour of the individual landslides. In the GIS layer, landslides were classified as fall and/or topple $(2.83 \%$ of the total landslide cells), slow (earth) flow (17.35\%), rapid flow $(5.13 \%)$, complex movement $(35.16 \%)$, rotational/translational slide $(34.54 \%)$, lateral spread $(0.16 \%)$, sinkhole $(0.03 \%)$, and undefined slope movement $(4.8 \%)$.

Given the different geographical quality and completeness (Guzzetti et al., 2012) of the IFFI database (Trigila et al., 2010), we decided against using this source of landslide information to prepare the non-susceptibility landslide models for Italy. Instead, we used the landslide information obtained from the IFFI database to evaluate the performance of the non-susceptibility model (see Sect. 4). This allowed us to validate the non-susceptibility models using independent landslide information.

\subsubsection{Landslide information in Spain}

For Spain, the IGME made geomorphological landslide inventory maps available to us for three areas in the Pyrenees, Murcia, and the Tramuntana range in Majorca $(\mathrm{N}, \mathrm{O}$, and $\mathrm{P}$ in Table 1). Collectively, the three inventories show 519 landslides, with $60 \mathrm{~m}^{2}<A_{\mathrm{L}}<1.82 \mathrm{~km}^{2}$, an average landslide area $A_{\mathrm{L}}=75160 \mathrm{~m}^{2}$, a total landslide area $A_{\mathrm{LT}}=27.24 \mathrm{~km}^{2}$, and an average density of 0.4 landslides per square kilometre. Table 1 lists the main characteristics of the landslides in the three inventory maps in Spain.

We used the landslide information in Spain to evaluate the performance of the zonation of non-susceptible landslide areas for the Mediterranean region (see Sect. 5.2).

\section{Non-susceptibility landslide models}

To determine the areas in Italy that are expected to be non-susceptible to landslides, we prepared three different 

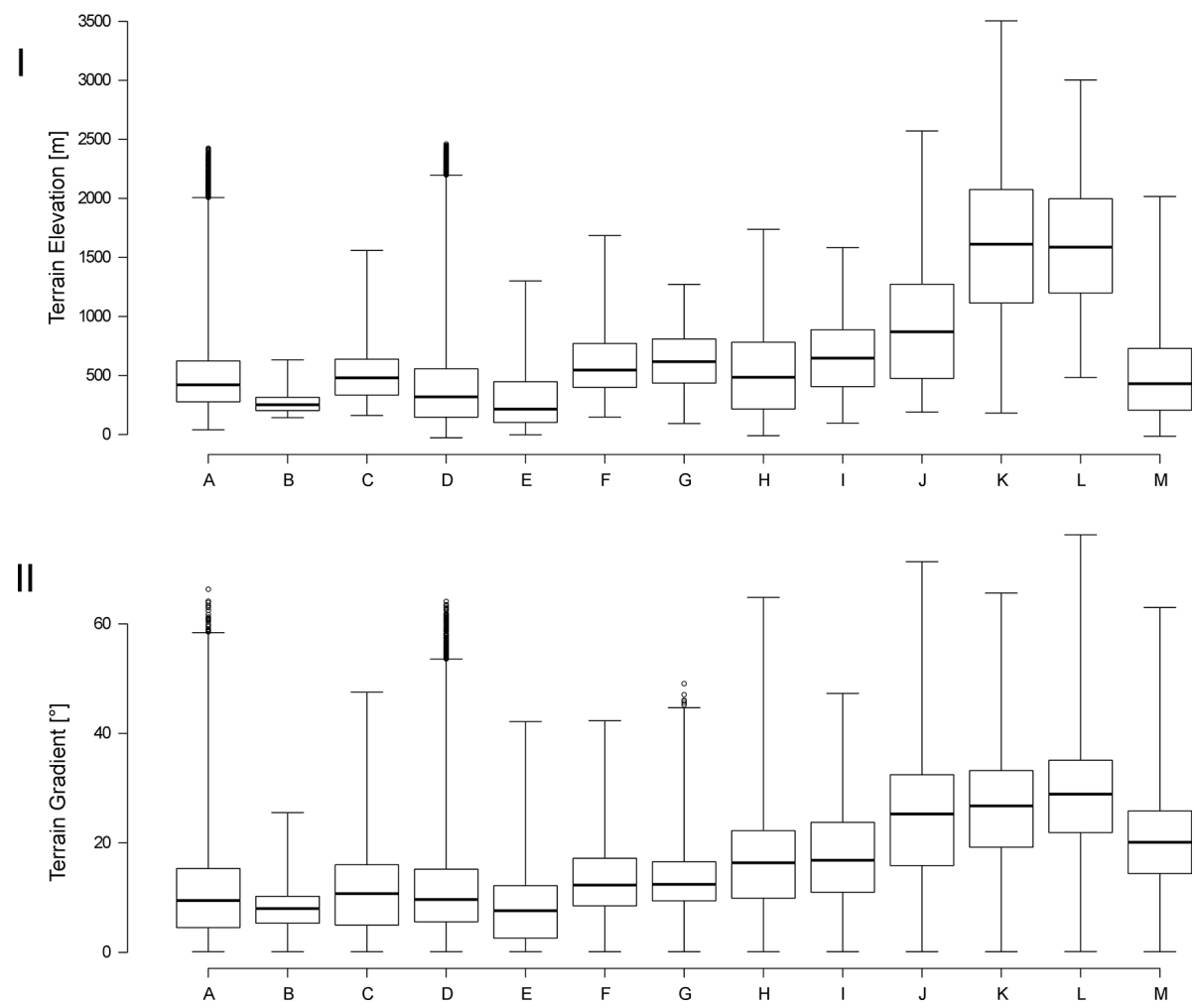

Figure 3. Terrain morphology in the 13 areas in Italy for which regional landslide inventories were available. See Fig. 2 for the location of the areas. Box plots show the distributions of (upper panel) terrain elevation and (lower panel) terrain gradient. The whiskers extend to the most extreme data point which is no more than 4 times the interquartile range from the box. Legend: (A) Umbria, (B) Collazone, (C) Upper Tiber River, (D) Marche, (E) Basento and Cavone, (F) Staffora, (G) Setta, (H) Messina, (I) Lunigiana, (J) Lecco, (K) Valcamonica, (L) Valseriana, (M) Imperia. See Table 1 for details on the study areas and the inventory maps, and for references.

models. The three models exploit the same landslide information obtained from the available inventory maps (Fig. 2 and Table 1), and two topographic indexes computed from the SRTM DEM, i.e. the regional relative relief $R$ (in metres) and the local terrain slope $S$ (in degrees). We computed $R$ in a $15 \times 15$-cell circular moving window and $S$ in a $3 \times 3$-cell square moving window. We used kernels of significantly different sizes to capture different morphometric characteristics of the landscape, and to reduce the collinearity between the two terrain variables. Computation of relative relief $R$ was straightforward and was performed using the $r$. neighbors module of GRASS GIS (Geographic Resources Analysis Support System). Computation of terrain slope $S$ was more problematic, because the SRTM DEM was in geographical coordinates. We computed $S$ in the original longitude-latitude coordinates. For this purpose, we calculated the width of each grid cell in the EW (longitude, $\delta x_{i, j}$ ) and the NS (latitude, $\delta y_{i, j}$ ) directions. Denoting $\delta x_{0}=\frac{2 \pi a \delta \theta}{360}$ the size of a $\delta \theta$-by- $\delta \theta$-degree cell, $a=6378137.0000 \mathrm{~m}$ along the major axis and $b=6356752.3142 \mathrm{~m}$ along the minor axis of the WGS84 ellipsoid (corresponding to a flattening ratio $f=1 / 298.257223563$ and eccentricity $\left.e^{2}=\left(a^{2}-b^{2}\right) / a^{2}\right)$, we calculated the size of each cell as a function of the local latitude $\theta_{i, j}$ as:

$$
\begin{aligned}
\delta x_{i, j} & =\delta x_{0} \cos \theta_{i, j} \\
\delta y_{i, j} & =\frac{a\left(1-e^{2}\right)}{\left(1-e^{2} \sin ^{2} \theta_{i, j}\right)^{3 / 2}} \delta \theta .
\end{aligned}
$$

Using the above definitions, we calculated the slope $S_{i, j}$ in the $i$ th row, $j$ th column cell as:

$S_{i, j}=\arctan \left(\left(\frac{\delta z_{i, j}}{\delta x_{i, j}}\right)^{2}+\left(\frac{\delta z_{i, j}}{\delta y_{i, j}}\right)^{2}\right)^{1 / 2}$,

where $z_{i, j}$ is the local terrain elevation,

$$
\begin{aligned}
& \frac{\delta z_{i, j}}{\delta x_{i, j}} \\
& =\frac{\left(z_{i+1, j+1}+2 z_{i+1, j}+z_{i+1, j-1}\right)-\left(z_{i-1, j+1}+2 z_{i-1, j}+z_{i-1, j-1}\right)}{8 \delta x_{i, j}}
\end{aligned}
$$


Table 1. Information on regional landslide inventory maps used in this work. See Fig. 2 for the location of the inventory maps.

\begin{tabular}{|c|c|c|c|c|c|c|c|c|c|c|c|}
\hline \multirow[t]{2}{*}{ ID } & \multirow{2}{*}{$\begin{array}{l}\text { Study area } \\
\qquad\left[\mathrm{km}^{2}\right]\end{array}$} & \multirow{2}{*}{$\begin{array}{l}\text { Inventory } \\
\text { Type }\end{array}$} & \multicolumn{3}{|c|}{ Landslide } & \multirow{2}{*}{$\begin{array}{r}\text { Min area } \\
\qquad\left[\mathrm{m}^{2}\right]\end{array}$} & \multirow{2}{*}{$\begin{array}{c}\text { Max area } \\
{\left[\mathrm{km}^{2}\right]}\end{array}$} & \multirow{2}{*}{$\begin{array}{l}\text { Mean area } \\
\qquad\left[\mathrm{m}^{2}\right]\end{array}$} & \multicolumn{2}{|l|}{ Scale } & \multirow{2}{*}{ Source } \\
\hline & & & $\#$ & {$\left[\mathrm{~km}^{2}\right]$} & Type (\%) & & & & Aerial photographs & Map & \\
\hline \multirow{2}{*}{ A } & 8456 & GM & 44039 & 545 & sm (98) & 70 & 1.85 & 12382 & $1: 13 \mathrm{k}$ to $1: 73 \mathrm{k}$ & $1: 10 \mathrm{k}$ & [1] \\
\hline & 1500 & $\mathrm{EV}$ & 4234 & 13 & $\operatorname{sm}(100)$ & 40 & 0.15 & 2998 & $1: 20 \mathrm{k}$ & $1: 10 \mathrm{k}$ & {$[2]$} \\
\hline B & 80 & MT & 2849 & 11 & $\operatorname{sm}(100)$ & 36 & 0.07 & 3923 & $1: 13 \mathrm{k}$ to $1: 33 \mathrm{k}$ & $1: 10 \mathrm{k}$ & [3] \\
\hline $\mathrm{C}$ & 4098 & GM & 16731 & 364 & sm (100) & 170 & 1.08 & 21751 & $1: 33 \mathrm{k}, 1: 13 \mathrm{k}$ & $1: 25 \mathrm{k}$ & [4] \\
\hline $\mathrm{D}$ & 9366 & GM & 8713 & 880 & $\operatorname{sm}(81)$ & 2711 & 4.38 & 100642 & $1: 33 \mathrm{k}$ & $1: 25 \mathrm{k}$ & [5] \\
\hline $\mathrm{E}$ & 1411 & GM & 1843 & 167 & sm (100) & 2554 & 3.68 & 90643 & $1: 33 \mathrm{k}$ & $1: 25 \mathrm{k}$ & $\mathrm{u}$ \\
\hline $\mathrm{F}$ & 274 & MT & 3746 & 187 & $\operatorname{sm}(90)$ & 145 & 0.18 & 49862 & $1: 15 \mathrm{k}$ to $1: 40 \mathrm{k}$ & $1: 10 \mathrm{k}$ & {$[6]$} \\
\hline G & 317 & GM & 847 & 63 & na & 437 & 1.40 & 74591 & na & na & $\mathrm{u}$ \\
\hline \multirow{2}{*}{$\mathrm{H}$} & 2326 & GM & 6293 & 288 & sm (95) & 107 & 3.88 & 46524 & $1: 29$ to $1: 33 \mathrm{k}$ & na & $\mathrm{u}$ \\
\hline & 19 & EV & 31 & 0.05 & $\operatorname{sm}(100)$ & 39 & 0.02 & 1654 & $1: 3500,1: 4500$ & $1: 10 \mathrm{k}$ & [7] \\
\hline I & 358 & GM & 140 & 59 & $\operatorname{sm}(100)$ & 15705 & 7.26 & 419799 & $1: 33 \mathrm{k}, 1: 20 \mathrm{k}$ & $1: 10 \mathrm{k}$ & $\mathrm{u}$ \\
\hline $\mathrm{J}$ & 605 & GM & 1449 & 13 & $\operatorname{sm}(38), \operatorname{rf}(58)$ & 21 & 2.09 & 8823 & na & na & [8] \\
\hline K & 1449 & GM & 980 & 94 & $\operatorname{sm}(83)$ & 118 & 2.68 & 95920 & na & na & [8] \\
\hline $\mathrm{L}$ & 269 & GM & 249 & 24 & $\operatorname{sm}(78)$ & 1435 & 1.57 & 94936 & na & na & {$[8]$} \\
\hline \multirow{2}{*}{ M } & \multirow{2}{*}{500} & GM & 626 & 17 & $\operatorname{sm}(90)$ & 105 & 0.34 & 26791 & $1: 55 \mathrm{k}$ & $1: 10 \mathrm{k}$ & \multirow{2}{*}{ [9] } \\
\hline & & EV & 768 & 0.7 & $\operatorname{sm}(100)$ & 50 & 0.07 & 868 & $1: 13 \mathrm{k}, 1: 5 \mathrm{k}$ & $1: 10 \mathrm{k}$ & \\
\hline $\mathrm{N}$ & 68 & GM & 255 & 14 & na & 155 & 1.06 & 56025 & na & na & [10] \\
\hline $\mathrm{O}$ & 1282 & GM & 228 & 12 & na & 60 & 1.82 & 53773 & na & na & {$[10]$} \\
\hline $\mathrm{P}$ & 12 & GM & 36 & 0.6 & na & 273 & 0.13 & 16834 & na & na & [10] \\
\hline
\end{tabular}

(A) Umbria region, central Italy. (B) Collazzone, Umbria, central Italy. (C) Upper Tiber River basin, central Italy. (D) Marche, central Italy. (E) Basento and Cavone catchments, southern Italy. (F) Staffora catchment, Lombardia, northern Italy. (G) Setta catchment, Emilia-Romagna, northern Italy. (H) Messina, Sicily, southern Italy. (I) Lunigiana,

Toscana, northern Italy. (J) Lecco, Lombardia, northern Italy. (K) Valcamonica, Lombardia, northern Italy. (L) Valseriana, Lombardia, northern Italy. (M) Imperia, Liguria, northern Italy. (N) Pyrenees, northern Spain. (O) Murcia, southern Spain. (P) Tramuntana range, Majorca, Spain. Legend: GM - geomorphological landslide inventory map; EV - event landslide inventory map; MT - multi-temporal landslide inventory map; sm - slide + slow earth flow + complex and compound movement; rf - rock fall; na information not available; $\mathrm{u}$ - unpublished. References: [1] Antonini et al. (2002), [2] Cardinali et al. (2000), [3] Guzzetti et al. (2006, 2009) and Galli et al. (2008),

[4] Cardinali et al. (2001), [5] Antonini et al. (1993), [6] Guzzetti et al. (2005a), [7] Ardizzone et al. (2012), [8] Antonini et al. (2000), [9] Guzzetti et al. (2004), [10] G. Herrera Garcia and R. M. Mateos, personal communication, 2013.

and

$\frac{\delta z_{i, j}}{\delta y_{i, j}}$

$=\frac{\left(z_{i+1, j+1}+2 z_{i, j+1}+z_{i-1, j+1}\right)-\left(z_{i+1, j-1}+2 z_{i, j-1}+z_{i-1, j-1}\right)}{8 \delta y_{i, j}}$.

These are the partial derivatives of the polynomial that approximates topography locally (Horn, 1981).

\subsection{Linear regression model}

To prepare our first non-susceptible landslide model, we modified the approach proposed by Godt et al. (2012), who were first to propose a threshold model for the zonation of non-susceptible landslide areas based on the use of terrain variables obtained from digital elevation data. Their approach was based on the empirical observation that topography conditions landslide susceptibility.

Godt et al. (2012) used an aggregate of 16000 landslide point locations obtained from inventories prepared at different scales for five geographical areas in the conterminous US (New Mexico, New Jersey, Oregon, California, North Carolina), and two morphometric indexes computed from the SRTM data. Using the digital elevation data, Godt et al.
(2012) prepared maps of relative relief $R$ and terrain slope $S$ for their study area, and sampled $R$ and $S$ for single points representing individual landslides in their five inventories. For each inventory, they constructed an empirical cumulative distribution function (ECDF) for the two morphometric indexes $(R$ and $S$ ), and sampled the 10th percentile from each ECDF. The five $(R, S)$ empirical data points were plotted in a single graph, and fitted by a linear function. The linear fit was then used as a threshold model to separate terrain conditions where landslide susceptibility was considered negligible (below the threshold line) from terrain conditions where "some" landslide susceptibility was expected (above the threshold line) (Godt et al., 2012).

Considering the size of the landslides, many of which are large and very large in our study areas (Table 1), and the complexity is typical of the landslide terrain (Pike, 1988), use of a single point to capture morphometric conditions representative of non-susceptible terrain was an unnecessary limitation for us, given the fact that the landslide information available for Italy (Fig. 2) consisted of polygons showing the location, shape, and size of the individual landslides. The area information is superior to the point information used by Godt et al. (2012), and we exploited the additional information. 
First, we computed the frequency distribution of the relative relief $R$ and of the terrain slope $S$ for all the grid cells in each single landslide in an inventory. Next, for each inventory, we prepared ECDFs for the 50th percentile (median) of the two terrain variables, $R$ and $S$, in all the mapped landslides. As an example, Fig. 4 shows the ECDFs of the median (50th percentile, red line) of $R$ and $S$ for all the landslides shown in the Valseriana inventory ( $\mathrm{L}$ in Fig. 2 and Table 1). The same graph also shows the ECDFs for the 5th, 25th, 75th, and 95th percentiles of the $R$ and $S$ values. The dispersion of the values around the median (red line) measures the variability of the terrain variables. Figure 5 show the ECDFs of the median of $R$ and $S$ for all the investigated inventories. Lastly, for each inventory, we selected the 5th percentile of the ECDFs of the median of relative relief $R$ and terrain slope $S$ (Fig. 5), and we plotted the $13\left(R_{50}, S_{50}\right)$ data points in a single plot (Fig. 6).

To determine the threshold model, we adopted the 5th percentile as a reasonable lower threshold to separate between negligible and some landslide susceptibility (Godt et al., 2012). Inspection of Fig. 6 reveals that the 13 data points $\left(R_{50}, S_{50}\right)$ align along a linear trend. We fitted the data points with a linear regression model (LNR) to obtain:

$S_{50}=3.448+0.040 R_{50}\left(0<R_{50}<350 \mathrm{~m}, 0<S<18^{\circ}\right)$

with a residual standard error $R_{\mathrm{SE}}=1.126^{\circ}$.

We used the LNR model represented by Eq. (6) to prepare the zonation of Italy shown in map I of Fig. 7. In the LNR map, the red (non-susceptible) areas are areas where landslide susceptibility is expected to be negligible, with a $5 \%$ error expected. In the other areas, some susceptibility to landslides is expected. In Fig. 7I, the non-susceptible (red) areas are characterized by $\left(R_{50}, S_{50}\right)$ data points below or on the LNR threshold line, and the other areas have $\left(R_{50}, S_{50}\right)$ data points above the LNR threshold (Fig. 6).

\subsection{Quantile regression models}

The LNR model, and the associated terrain zonation (I in Fig. 7), was prepared considering a single point to represent each inventory (Fig. 6). Seeing the different sizes of the study areas, and the different number of landslides in each study area (Table 1), this was also a limitation. Hence, to construct the other two non-susceptibility models, we used all the values of regional relative relief $R$ and local terrain slope $S$ computed for all the grid cells ( 3 -arcsecond resolution) in all the landslide polygons shown in the 13 inventory maps. This is a total of $354406(R, S)$ empirical data points. We plotted all the $(R, S)$ data points in Fig. 8, and we searched for a lower threshold to the cloud of the empirical data points. To determine the lower threshold, we exploited quantile regression (Koenker, 2005) testing a linear model (QLR - our second non-susceptibility model) and a non-linear (exponential) model (QNL - our third non-susceptibility model). For both models, we instructed the quantile regression to search for the $5 \%$ lower boundary, i.e. a regression line that leaves $5 \%$ of the empirical data points below the best fit line.

The linear quantile regression (QLR) model resulted in the function:

$S=0.245+0.032 R\left(0<R<1000 \mathrm{~m}, 0<S<70^{\circ}\right)$,

with a residual standard error $R_{\mathrm{SE}}=7.970^{\circ}$, whereas quantile regression of a non-linear (QNL) model resulted in the exponential function:

$S=3.539 \exp (0.0028 \times R)\left(0<R<1000 \mathrm{~m}, 0<S<70^{\circ}\right)$,

with a residual standard error $R_{\mathrm{SE}}=8.534^{\circ}$.

We used the quantile regression models represented by Eqs. (7) and (8) to prepare the binary zonation of Italy shown in maps II and III in Fig. 7. As before, the red (nonsusceptible) areas in the maps are areas where landslide susceptibility is expected to be negligible, with a $5 \%$ error expected. In the other areas some susceptibility to landslides is expected. In Fig. 7 II and III, the non-susceptible (red) areas are characterized by $\left(R_{50}, S_{50}\right)$ pairs below or on the QLR and the QNL threshold models, and the other areas have $\left(R_{50}, S_{50}\right)$ pairs above the thresholds.

\section{Optimal non-susceptibility model for Italy}

Figure 7 compares the three non-susceptibility threshold models for Italy. The QLR model (map II in Fig. 7) classifies the smallest portion of the territory $(21.9 \%)$ as nonsusceptible, followed by the QNL model (map III in Fig. 7) (41.9\%), and by the LNR model (map I in Fig. 7) (61.9\%). The differences are significant. Visual inspection of Fig. 7 reveals the differences, and suggests that the QLR model is too pessimistic (conservative), because it does not recognize large regions in flood plains and other flat areas, in which landslides are clearly not expected, as non-susceptible (Fig. 7 II-b). Conversely, the LNR model is too optimistic (liberal), because it classifies large parts of the slopes, on which landslides are expected, as non-susceptible (Fig. 7 I-b). The QNL model classifies the flood plains and other flat areas as nonsusceptible, and correctly classifies most of the sloping terrain. Overall, we consider the QNL model (Fig. 7 III-b) neither pessimistic nor optimistic.

We checked the proportion of empirical data points below the LNR, the QLR, and the QNL threshold models. We found that the LNR model leaves $39.4 \%$ of the empirical points below the threshold, while the QLR and the QNL models respectively leave 5.0 and $5.3 \%$. Considering the large dispersion of the empirical data (Fig. 8), we consider the two quantile threshold models, QLR and QNL, substantially equivalent in their ability to leave the prescribed number of points below the model threshold lines. We note that the QNL model predicts a negligible susceptibility for $S<3.5^{\circ}$, regardless of the regional relative relief $R$, and the QLR model predicts a negligible susceptibility only for $S<0.3^{\circ}$. 

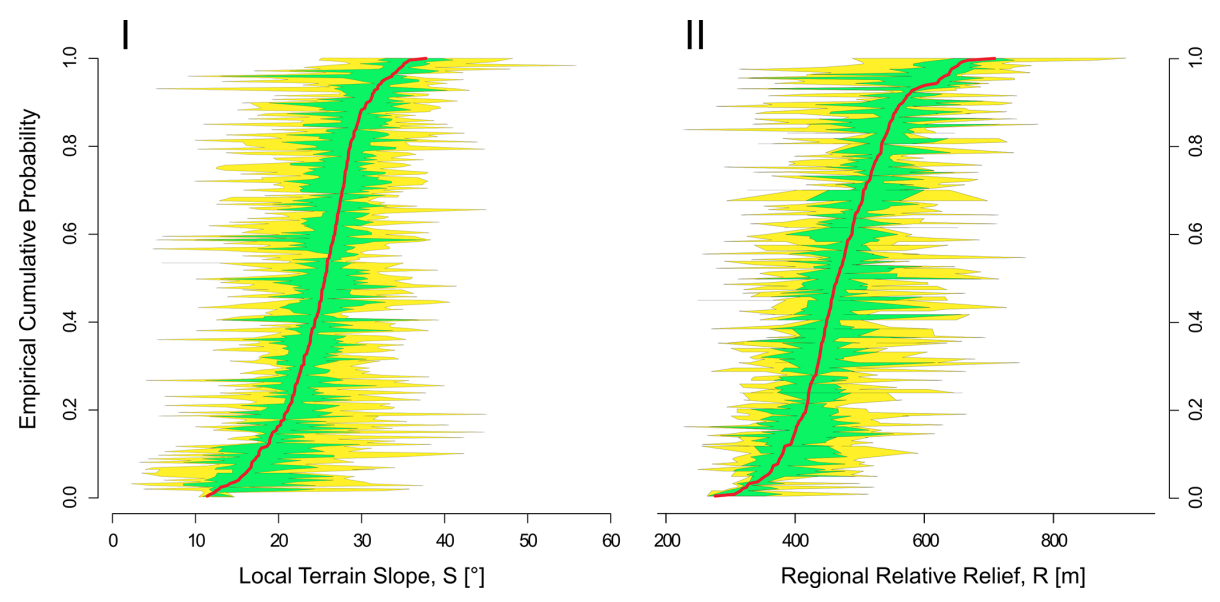

Figure 4. Empirical cumulative distribution function (ECDF) of (I) local terrain slope $S$ and (II) regional relative relief $R$ computed for each landslide shown in the Valcamonica inventory map - L in Table 1 (Antonini et al., 2000). Red line shows ECDF for the median (50th percentile), green area shows 25 th-75th percentile range, yellow area shows 5 th-95th percentile range.
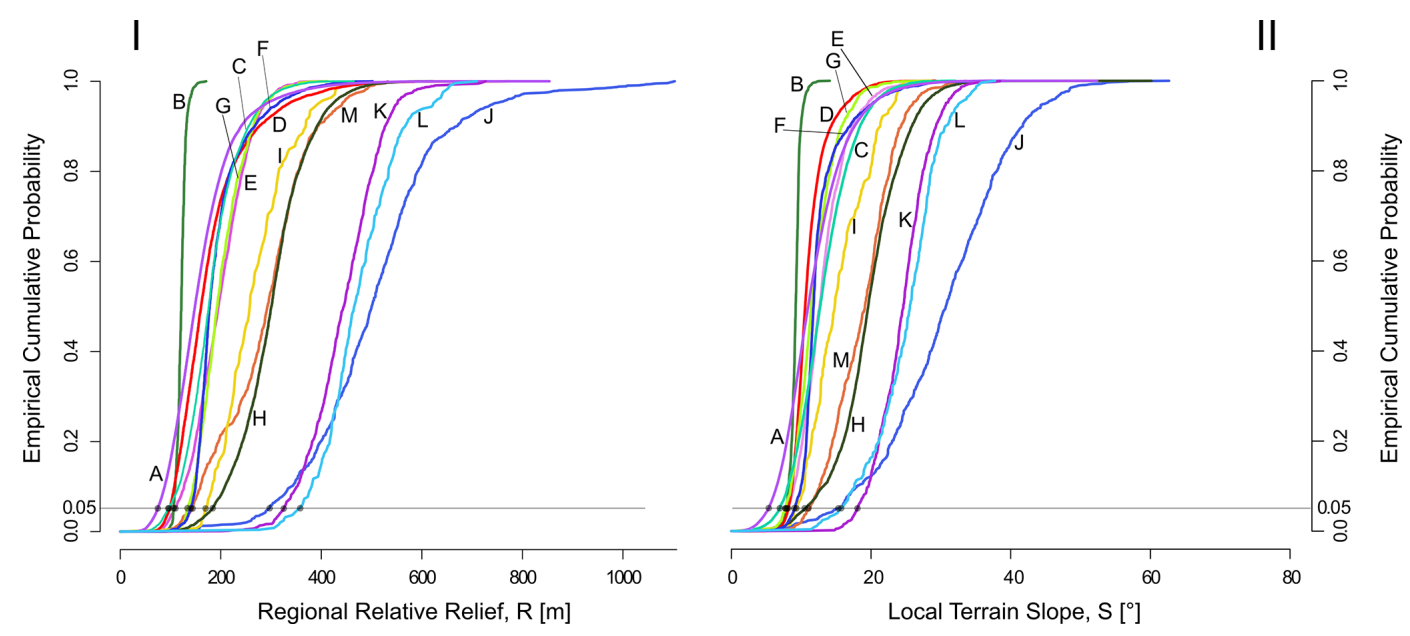

Figure 5. Empirical cumulative distribution functions (ECDFs) for the median (50th percentile) of the values of the regional relative relief $R$ and the local terrain slope $S$, for the 13 landslide inventories. Horizontal lines show $5 \%$ values of $R_{50}$ and $S_{50}$. Black dots along the horizontal lines represent the empirical $R_{50}$ and $S_{50}$ values used to prepare Fig. 6. Legend: (A) Umbria, (B) Collazone, (C) Upper Tiber River, (D) Marche, (E) Basento and Cavone, (F) Staffora, (G) Setta, (H) Messina, (I) Lunigiana, (J) Lecco, (K) Valcamonica, (L) Valseriana, (M) Imperia. See Table 1 for details on the study areas and the inventory maps. See Fig. 2 for the location of the areas.

To help select the most appropriate (i.e. "optimal”) model for the zonation of non-susceptible landslide areas in Italy, we tested the three models against independent landslide information, represented by the IFFI data set. In the GIS, we intersected the three maps for non-susceptible areas obtained using the LNR, the QLR, and the QNL models (Fig. 7) with the landslides shown in the IFFI data set, in raster format. To quantify the differences, we used the matching index I (Carrara et al., 1992; Galli et al., 2008), which measures the overall proportion of landslide cells that overlay non-susceptible cells in each landslide map, i.e. $I=O_{\mathrm{c}} / N_{\mathrm{c}} \times 100$, where $O_{\mathrm{c}}$ is the total number of landslide cells overlaying nonsusceptible cells, and $N_{\mathrm{c}}$ is the total number of landslide cells. The matching index $(I)$ is equivalent to the false positive rate (FPR), the ratio of the false positives (FP) over the sum of the True Negatives and false positives (TN + FP).

The LNR, the QLR, and the QNL threshold models, and their associated maps (Fig. 7), were obtained using landslide inventories containing chiefly translational and rotational slides, earth flows, and complex movements (according to Cruden and Varnes, 1996). We therefore tested the three threshold models against (i) the entire IFFI inventory, showing all landslide types (falls and topples, complex landslides, slow flows, rapid flows, translation and rotational slides, and lateral spreads), and (ii) a subset of the IFFI inventory, showing translational and rotational slides, slow flows, and complex movements. Results are summarized in Table 2. 
Table 2. Proportion of landslide cells shown in the IFFI data set (Trigila et al., 2010) in non-susceptible cells classified by the three threshold models: LNR - linear model (Eq. 6), QLR - quantile linear model (Eq. 7), and QNL - quantile non-linear model (Eq. 8). See text for explanation.

Falls/topples, complex movements, slow/rapid flows, translational/rotational slides, lateral spreads.

\begin{tabular}{ccccc}
\hline Model & $\|$ & LNR [\%] & QLR [\%] & QNL [\%] \\
\hline & $\|$ & 43.37 & 5.97 & 6.27 \\
\hline
\end{tabular}

Translational/rotational slides, slow flows, complex movements

\begin{tabular}{ccccc}
\hline Model & $\|$ & LNR [\%] & QLR [\%] & QNL [\%] \\
\hline & $\|$ & 43.77 & 5.66 & 5.83 \\
\hline
\end{tabular}

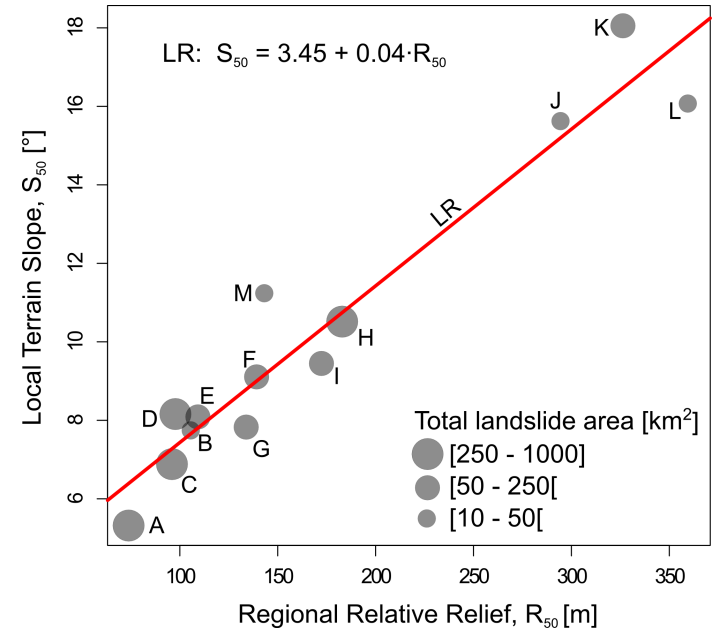

Figure 6. Plot of the 5th percentiles for the empirical cumulative distribution function (ECDF) for the median of local terrain slope $S_{50}$ and general relative relief $R_{50}$. The line represents best linear fit LR (Eq. 6). Increasing number of landslides in the inventory is shown by symbols of increasing size. Legend: (A) Umbria, (B) Collazzone, (C) Upper Tiber River, (D) Marche, (E) Basento and Cavone, (F) Staffora, (G) Setta, (H) Messina, (I) Lunigiana, (J) Lecco, (K) Valcamonica, (L) Valseriana, (M) Imperia. See Table 1 for details on the study areas, the inventory maps and the references. See Fig. 2 for the location of the areas.

Comparison of the LNR model to the entire IFFI data set revealed that a large proportion of the IFFI landslides were in non-susceptible areas $(I=43.37 \%)$. The result did not change significantly when we considered the subset of the IFFI data set showing translational and rotational slides, earth flows, and complex movements $(I=43.77 \%)$ (Table 2). The figures confirm that the LNR model is too optimistic, and that the LNR model did not perform well in detecting non-susceptible landslide areas in Italy. Further inspection of Table 2 reveals that the QLR (Fig. 7 II) and the QNL (Fig. 7 III) models performed significantly better, and
Table 3. Values of the matching index $I$ obtained comparing the QNL model (Map III in Fig. 7) with landslides shown in the IFFI database (Trigila et al., 2010), for different landslide types. See text for explanation.

\begin{tabular}{lr}
\hline Landslide type & I [\%] \\
\hline Fall and topple & 7.7 \\
Slow flow & 5.9 \\
Complex movement & 6.3 \\
Rapid flow & 11.5 \\
Translation and rotational slide & 5.3 \\
Undefined & 7.0 \\
Lateral spread & 20.9 \\
Sinkhole & 13.8 \\
\hline
\end{tabular}

equally well, with matching indexes: $5.97 \leq I \leq 6.27$. These figures are slightly above the expected percentage of misclassifications $(5 \%)$. Both models performed slightly better when considering the subset of the IFFI data set listing translational and rotational slides, earth flows, and complex movements. This was expected, because the 13 regional inventories used to construct the model primarily show these landslide types.

Based on all of these findings, we conclude that the QNL model is the best of the three threshold models, and we adopt QNL as the optimal model to represent non-susceptible landslide areas in Italy. Readers interested in using the map showing non-susceptible landslide areas in Italy, and in the Mediterranean Region, can find information on how to access the map through a specific WMS (see http://geomorphology. irpi.cnr.it/tools/landslide-susceptibility-assessment/ non-susceptible-landslide-areas/). We expect that this will contribute to validate the non-susceptibility zonation with additional independent landslide information.

We investigate further the performance of the QNL model studying the degree of matching between the nonsusceptibility zonation and the IFFI data set (i) for different 

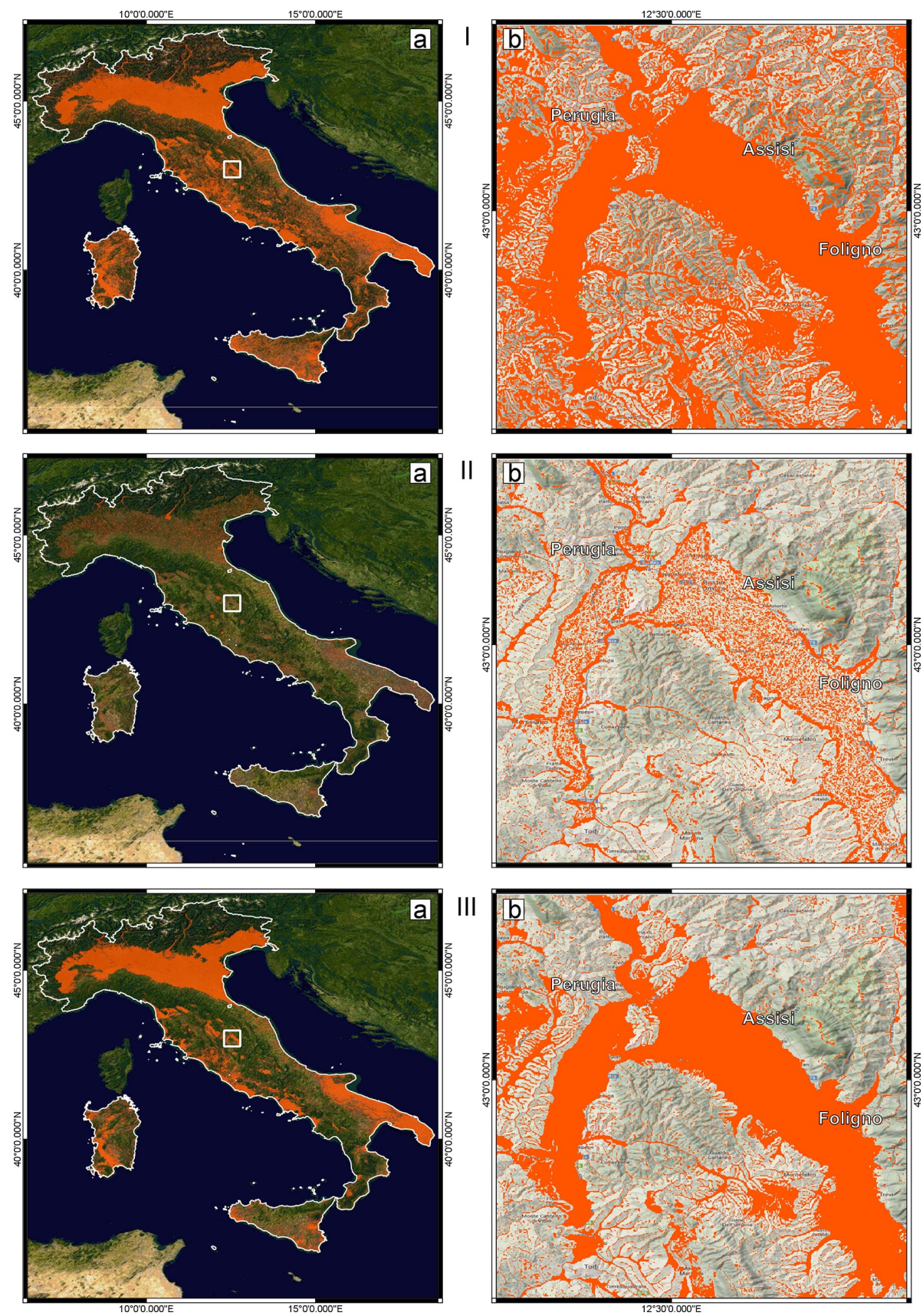

Figure 7. Maps showing zonation of non-susceptible landslide areas in Italy. Red shows non-susceptible areas, and other colours show terrain outside non-susceptible landslide areas. (Ia) Map prepared adopting the LNR model, Eq. (6). (IIa) Map prepared adopting the QLR model, Eq. (7). (IIIa) Map prepared adopting the QNL model, Eq. (8). (Ib), (IIb) and (IIIb) show enlargements for a portion of study area in Umbria, central Italy. See text for explanation. Background images: ${ }^{{ }^{\circ}} 2014$ Google.

landslide types (Table 3), (ii) in the 20 administrative regions in Italy (Table 4), and (iii) in the 13 study areas for which the regional inventories were available to us (Table 5).

Table 3 lists the matching indexes for the different landslide types. Best results are obtained for the rotational/traslational slides. The matching index for these landslide types $(I=5.3 \%)$ is equivalent to the number of cells that the QNL model leaves below the threshold line (5.3\%). The QNL model failed to detect non-susceptible areas for lateral spreads $(I=20.9 \%)$, sinkholes $(13.8 \%)$, and rapid flows $(11.5 \%)$. Results improve for slow flows $(5.9 \%)$, complex movements $(6.3 \%)$, undefined slope failures $(7.0 \%)$, and for falls and topples $(7.7 \%)$. 


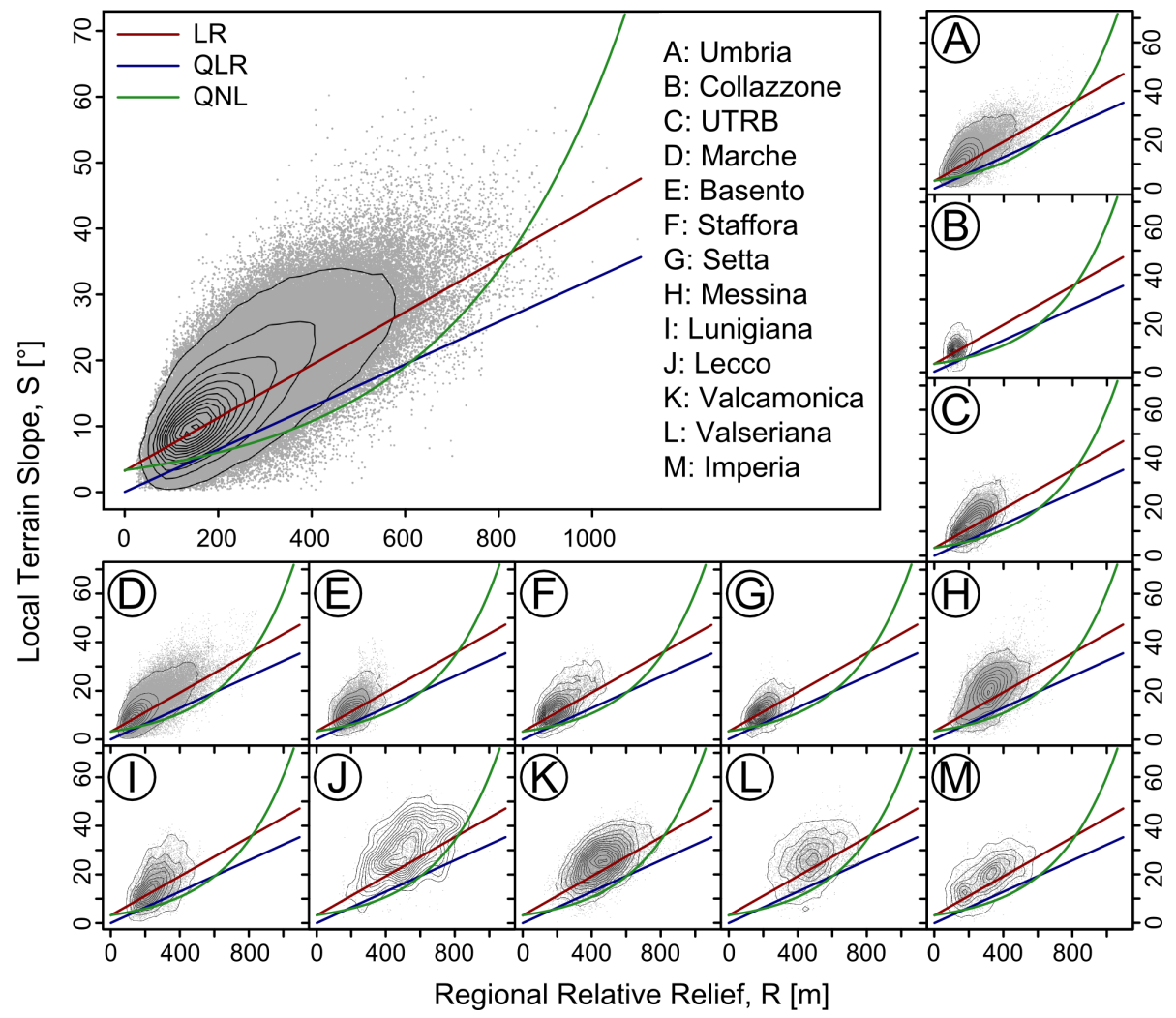

Figure 8. Plots show regional relative relief $R$ ( $x$ axis) and local terrain slope $S$ ( $y$ axis) computed for all grid cells in all landslides shown in the 13 regional inventory maps used in this study (Fig. 2 and Table 1). Red line shows LNR model, Eq. (6). Blue line shows QLR model, Eq. (7). Green line shows QNL model, Eq. (8). See text for explanation. Legend: (A) Umbria, (B) Collazzone, (C) Upper Tiber River, (D) Marche, (E) Basento and Cavone, (F) Staffora, (G) Setta, (H) Messina, (I) Lunigiana, (J) Lecco, (K) Valcamonica, (L) Valseriana, (M) Imperia. See Table 1 for details on the study areas, the inventory maps, and the references. See Fig. 2 for the location of the areas.

Table 4 lists the matching indexes for the 20 administrative regions in Italy. We focus on the Piemonte, Molise, and Campania regions (Fig. 2), because (i) they are representative of different terrain an physiographical settings in Italy (Guzzetti and Reichenbach, 1994), (ii) the quality of the landslide information in the IFFI data set is good or very good in these regions (Trigila et al., 2010), and (iii) our QNL model was constructed using landslide information outside of these three regions. Results indicate that, in the Piemonte and the Molise regions, the QNL model performed well without considering $(I=4.97 \%$ for Piemonte and $I=5.34 \%$ for Molise) and considering $(I=5.23 \%$ for Piemonte and $I=5.72 \%$ for Molise) the complex movements. In Campania, the model performance was slightly worse $(I=7.16 \%$, considering the complex movements, and $I=7.27 \%$, without considering the complex movements). In the other regions, the performance of the QNL model was also acceptable, with better results obtained without considering the complex movements (Table 4). The worst results were obtained in Sardegna ( $I=13.47 \%$, not considering the complex movements), and in Friuli-Venezia Giulia $(I=13.07 \%$, considering the complex movements). We attribute the geographical variations in the performance of the QNL model to different terrain conditions and to the quality of the IFFI inventory, which varies significantly in the different regions (Trigila et al., 2010).

Lastly, Table 5 lists the matching indexes computed for the different sources of landslide information. Overall, the matching indexes are in the range $2.48 \% \leq I \leq 8.26 \%$, with an average of $I=4.76 \%$ (std. dev. $=1.56 \%$ ). Particularly small values were obtained in the Valcamonica (L in Fig. 2) $(I=2.48 \%)$ and the Imperia (M in Fig. 2) $(I=2.52 \%)$ study areas, and large values were found in the Collazzone (B in Fig. $2(I=8.26 \%)$ and in the Lecco ( $\mathrm{J}$ in Fig. $2(I=8.13 \%)$ study areas. The average values of $I$ change slightly for the different sources of landslide information. When considering all landslides shown in the regional inventories, $I=4.56 \%$ (std. dev. $=1.54 \%$ ), which is marginally smaller than the prescribed $5 \%$. This was expected, as the regional inventories were used to construct the non-susceptibility threshold model. Interestingly, also the average values of $I$ obtained with consideration of the landslides shown in the IFFI data set are very close to the prescribed value of $5 \%(I=5.15 \%)($ std. dev. $=1.75 \%)$ and $I=4.57 \%$ (std. dev. $=1.42 \%$ ) for the subset with slides, 
Table 4. Values of the matching index $I$ obtained comparing the QNL model (Map III in Fig. 7) with landslides shown in the IFFI database (Trigila et al., 2010), for administrative regions in Italy. (a) The subset of the IFFI data set comprising slides, slow flows, and complex movements. (b) The subset of the IFFI data set comprising slides and slow flows. See text for explanation.

\begin{tabular}{lrr}
\hline Region & (a) [\%] & (b) [\%] \\
\hline Piemonte & 5.23 & 4.97 \\
Lombardia & 5.30 & 4.05 \\
Veneto & 6.33 & 6.21 \\
Liguria & 3.55 & 3.80 \\
Emilia-Romagna & 5.55 & 5.10 \\
Toscana & 5.36 & 5.65 \\
Umbria & 5.32 & 5.30 \\
Marche & 6.15 & 5.66 \\
Lazio & 9.33 & 11.10 \\
Abruzzo & 5.19 & 5.50 \\
Molise & 5.72 & 5.34 \\
Campania & 7.16 & 7.27 \\
Puglia & 8.14 & 9.15 \\
Basilicata & 4.90 & 4.87 \\
Calabria & 4.85 & 4.82 \\
Sicily & 7.58 & 7.40 \\
Sardegna & 8.07 & 13.47 \\
Valle d'Aosta & 7.12 & 5.54 \\
Trentino-Alto Adige & 11.43 & 6.74 \\
Friuli-Venezia Giulia & 13.07 & 10.22 \\
\hline Italy & 5.83 & 5.49 \\
\hline
\end{tabular}

earth flows, and complex movements. We consider the reduced spread in the average value of the matching index $I$ a measure of the uncertainty associated with our QNL threshold model.

\section{Applications}

We used the QNL model (map III in Fig. 7) to estimate the size of the Italian population living in areas where susceptibility to landslides is expected to be negligible, and to prepare a synoptic-scale zonation of non-susceptible landslide areas in the Mediterranean region.

\subsection{Size of the population of Italy living in non-susceptible areas}

We used the QNL model (map III in Fig. 7) to estimate the proportion of the population of Italy living in areas expected to be non-susceptible to landslides. For this purpose, we used a digital map of the census zones of Italy and the associated population information, distributed by the Italian National Institute of Statistics - ISTAT (http://www.istat.it). The map of the census zones subdivides the Italian territory in a total of $\sim 380000$ zones, ranging in size from a few tens of square
Table 5. Values of the matching index $I$ obtained comparing the QNL threshold model (Map III in Fig. 7) with landslides shown in the 13 regional inventory maps used in this study (Fig. 2, Table 1) and the IFFI database (Trigila et al., 2010), in the areas covered by the regional inventories. (a) All landslides shown in the regional inventory maps. (b) The subset of the IFFI data set comprising slides, slow flows, and complex movements. (c) The subset of the IFFI data set comprising slides and slow flows. See text for explanation.

\begin{tabular}{lccc}
\hline & (a) [\%] & (b) [\%] & (c) [\%] \\
\hline A - Umbria & 5.22 & 5.33 & 5.30 \\
B - Collazzone & 6.41 & 8.26 & 7.62 \\
C - Upper Tiber River & 4.61 & 4.85 & 4.63 \\
D - Marche & 6.88 & 6.23 & 5.75 \\
E - Basento and Cavone & 4.60 & 5.33 & 5.33 \\
F - Staffora & 4.20 & 5.10 & 5.11 \\
G - Setta & 4.12 & 3.36 & 3.48 \\
H - Messina & 2.73 & 5.23 & 5.01 \\
I - Lunigiana & 6.07 & 5.79 & 5.00 \\
J - Lecco & 6.42 & 8.13 & 3.35 \\
K - Valcamonica & 2.58 & 2.48 & 2.58 \\
L - Valseriana & 3.26 & 3.60 & 3.06 \\
M - Imperia & 2.52 & 3.24 & 3.04 \\
\hline
\end{tabular}

metres to $325 \mathrm{~km}^{2}$ (average $=0.8 \mathrm{~km}^{2}$ ). The size of the census zones varies: the zones are small to very small in urban areas, large in sub-urban areas, and large to very large in rural and mountain areas. For each census zone, the total number of residents in 2001 is available. In the GIS, we first transformed the map of the census zones in Italy to the WGS84 (EPSG 4326) longitude-latitude CRS. Next, we intersected the census zones with the map showing non-susceptible landslide areas in Italy (map III in Fig. 7). Lastly, we classified each census zone based on the proportion of non-susceptible cells in the census zones.

Using this approach, we identified 193051 census zones where the proportion of non-susceptible areas was $99 \%$ or larger. These census zones represent $50.5 \%$ of the total number of census zones, and cover $20.2 \%$ of the territory covered by census zones in Italy. Some 33.1 million people live in the non-susceptible census zones ( $57.5 \%$ of the total population of Italy in 2001). We infer that the remaining $42.5 \%$ of the population of Italy live in areas that are not non-susceptible. This corresponds to $\sim 24.5$ million people in 2001 .

The total number and the proportion of the population living in non-susceptible areas varies geographically (Table 6). Regions with the largest number of people living in non-susceptible areas include Lombardia, Veneto, Campania, Emilia-Romagna, and Puglia, and regions with the largest proportion of people living in non-susceptible areas include Emilia-Romagna (80.65\%), Veneto (79.31\%), Puglia $(74.41 \%)$, and Lombardia $(73.08 \%)$. These regions host some of the most populated areas in Italy, and some of the largest plains (Guzzetti and Reichenbach, 1994). Regions 
with the least number of people living in non-susceptible areas are Valle d'Aosta, Liguria, Molise, and Basilicata. The regions where the proportion of the population in areas that are not non-susceptible is largest are Basilicata $(86.35 \%)$, Molise $(86.99 \%)$, Liguria $(77.35 \%)$, and Valle d'Aosta $(74.25 \%)$. In these regions landscape is predominantly mountainous or hilly (Guzzetti and Reichenbach, 1994), and landslide areas abundant (Trigila et al., 2010).

Further inspection of Table 6 reveals no correlation between the total number or the proportion of people living in non-susceptible areas, the number of fatal landslide events and of landslide fatalities, and the landslide mortality rates in the 50-year period $1963-2012$. We note that $73 \%$ of the fatal landslide events in Italy in the period from AD 842 to May 2013 (P. Salvati, personal communication, 2014) were located outside the areas classified as non-susceptible in map III of Fig. 7. The percentage decreases to $70 \%$ if the more recent 1963-2012 period is considered.

We consider this a good result for the following reasons: firstly, fatal landslides in Italy are predominantly rapid to fast-moving landslides (e.g. rock falls, minor rock slides, soil slips, debris flows) (Guzzetti et al., 2005b). With a few exceptions, slow-moving translational and rotational slides, earth flows, and complex movements do not usually cause fatalities in Italy. The latter are the predominant types of movements in the regional inventories used to construct the nonsusceptibility threshold model. Secondly, fatal landslides can be of very small size, and controlled by local terrain conditions that are not captured by the morphometric information used to construct our non-susceptibility model. Thirdly, fatal landslides can travel significant distances from their source areas, and into areas where terrain is gentle and relief is limited (e.g. debris flows depositing on a debris fan, rock falls reaching the alluvial plain). Fourthly, no information on the vulnerability to landslides was used to construct the non-susceptibility model. Lastly, the human consequences of landslides are very difficult to predict. We maintain that our synoptic-scale model, capable of determining where $73 \%$ (70\% in the most recent period) of the fatal landslide events have occurred (i.e. in areas considered not to be non-susceptible) is a valuable model.

\subsection{Non-susceptible landslide areas in the Mediterranean region}

We hypothesized that the results obtained in Italy are applicable to other geographical areas with similar physiographical and landslide characteristics, and for which the SRTM DEM is available. To test this hypothesis, we applied the QNL model to the landmasses surrounding the Mediterranean Sea (Fig. 1). For each grid cell in the $5771205 \mathrm{~km}^{2}$ area, we used the values of the regional relative relief $R$ and the local terrain slope $S$ to determine if the cell was above or below the QNL threshold model. Grid cells for which the $(R, S)$ data points were below the threshold model were classified as non-susceptible. The result is shown in Fig. 9, where the red areas (i.e. the non-susceptible areas) cover $3652683 \mathrm{~km}^{2}$ $(63 \%)$ of the landmasses in the domain. In these areas, susceptibility is expected to be negligible. The other cells, with $(R, S)$ data points on or above the QNL threshold model, cover a total of $2118521 \mathrm{~km}^{2}$ (37\% of the study area), and represent areas that are not non-susceptible in the landmasses surrounding the Mediterranean Sea.

We tested the synoptic-scale terrain zonation for the Mediterranean region using independent landslide information in Spain (N, O, and P in Fig. 1 and Table 1). To quantify the geometrical differences between the location of the known landslides in the three inventories in Spain and the synoptic zonation of non-susceptible areas (Fig. 9), we computed the fraction of landslide cells $O_{\mathrm{c}}$ that overlaid the nonsusceptible cells $N_{\mathrm{c}}, I=O_{\mathrm{c}} / N_{\mathrm{c}} \times 100$, and found a matchning index $I=6.11 \%$. This value is slightly larger than the values obtained for Italy, and of the expected proportion of landslide cells in non-susceptible areas $(5 \%)$.

Based on the results of the validation performed in Spain, we conclude that the QNL model is adequate for identifying zones in which landslide susceptibility is expected to be negligible in the Mediterranean region (Fig. 9).

\section{Discussion}

As anticipated in the introduction, inspection of the literature reveals that little effort has been made to propose and test models to assess where landslides are not expected (Chung and Fabbri, 2003; Fabbri et al., 2003), i.e. where landslide susceptibility is expected to be negligible (Godt et al., 2012). This is surprising, because planners and decision-makers are equally interested, or more interested, in knowing where landslides are not foreseen or cannot occur in an area than knowing where susceptibility is high or very high (Guzzetti et al., 1999; Chung and Fabbri, 2003; Fabbri et al., 2003; Godt et al., 2012). In an attempt to fill this gap, we have proposed a new threshold-based model capable of outlining nonsusceptible landslide areas in Italy and the Mediterranean region.

The model exploits two morphometric variables, regional relative relief $R$ and local terrain slope $S$, to outline the areas in which landslides were not shown in the available landslide inventory maps. Then, two geomorphological inferences are made. First, in the areas where landslides were not shown in the inventory maps, landslides did not occur in the past. This is a strong inference, which proves reasonable only where the quality of the landslide map is good (Guzzetti et al., 2012). Second, landslides will not occur in the future in the areas in which they did not occur in the past. These two inferences are conceptually similar to the inferences made by geomorphologists when preparing landslide susceptibility models and associated terrain zonation, using heuristic (rule-based) or 
Table 6. Number and percentage of people living in areas where landslide susceptibility is expected to be negligible in Italy.

\begin{tabular}{|c|c|c|c|c|c|c|}
\hline Region & $\begin{array}{r}\text { "Non-susceptibile" } \\
\text { area [\%] }\end{array}$ & $\begin{array}{r}\text { Citizens in } \\
\text { non-susceptible } \\
\text { area [\#] }\end{array}$ & $\begin{array}{c}\text { Citizens in } \\
\text { non-susceptible } \\
\text { area [\%] }\end{array}$ & $\begin{array}{r}\text { Fatal } \\
\text { landslides } \\
(1963-2012) \text { [\#] }\end{array}$ & $\begin{array}{r}\text { Landslide } \\
\text { fatalities } \\
(1963-2012) \text { [\#] }\end{array}$ & $\begin{array}{c}\text { Landslide } \\
\text { mortality } \\
(1963-2012)\end{array}$ \\
\hline Molise & 23.28 & 334133 & 13.01 & 2 & 4 & 0.023 \\
\hline Basilicata & 26.92 & 616347 & 13.65 & 7 & 18 & 0.058 \\
\hline Liguria & 9.35 & 1587826 & 22.65 & 16 & 37 & 0.042 \\
\hline Calabria & 25.10 & 2034604 & 24.08 & 19 & 38 & 0.037 \\
\hline Valle d'Aosta & 12.55 & 119632 & 25.75 & 12 & 25 & 0.423 \\
\hline Abruzzo & 22.95 & 1291394 & 27.82 & 7 & 9 & 0.014 \\
\hline Marche & 22.03 & 1543531 & 27.87 & 9 & 11 & 0.016 \\
\hline Trentino-Alto Adige & 13.03 & 943414 & 34.09 & 54 & 355 & 0.810 \\
\hline Umbria & 28.00 & 850604 & 36.00 & 8 & 15 & 0.038 \\
\hline Sicily & 34.38 & 4968991 & 40.32 & 21 & 70 & 0.083 \\
\hline Sardegna & 41.49 & 1631880 & 49.02 & 11 & 15 & 0.028 \\
\hline Lazio & 45.33 & 5144187 & 47.72 & 15 & 24 & 0.010 \\
\hline Toscana & 30.95 & 3551049 & 57.23 & 30 & 68 & 0.039 \\
\hline Campania & 34.63 & 5787348 & 58.04 & 96 & 306 & 0.111 \\
\hline Piemonte & 42.15 & 4233649 & 62.98 & 52 & 137 & 0.063 \\
\hline Friuli-Venezia Giulia & 53.13 & 1212343 & 65.97 & 9 & 223 & 0.370 \\
\hline Lombardia & 59.54 & 9077266 & 73.08 & 40 & 123 & 0.028 \\
\hline Puglia & 82.67 & 4042899 & 74.41 & 6 & 12 & 0.006 \\
\hline Veneto & 66.39 & 4611136 & 79.14 & 26 & 1780 & 0.914 \\
\hline Emilia-Romagna & 56.21 & 4052909 & 80.65 & 2 & 49 & 0.025 \\
\hline Italy & 0.0 & 0.0 & 0.0 & 0 & 0 & 0.0 \\
\hline
\end{tabular}

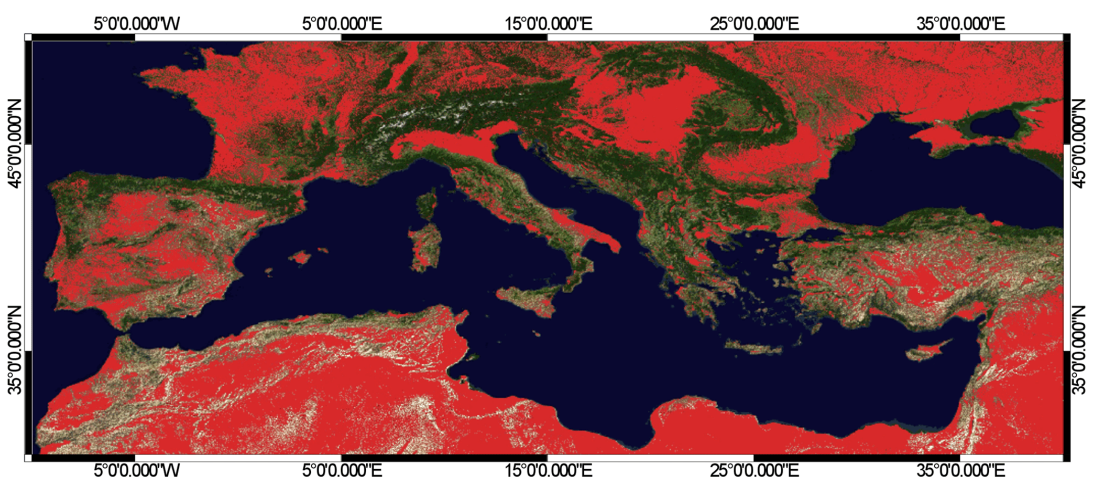

Figure 9. Map showing non-susceptible landslide area in the landmasses surrounding the Mediterranean Sea. Red shows non-susceptible areas, and other colours show terrain outside non-susceptible areas. Zonation was obtained using the QNL model, Eq. (8). See text for explanation. Background image: ${ }^{{ }} 2014$ Google.

statistical approaches (Chung and Fabbri, 1999; Fabbri et al., 2003; Guzzetti, 2005; Guzzetti et al., 1999, 2005a).

The threshold model determines, within a given accuracy measured by the proportion of accepted mis-classification (i.e. 5\%), where landslide susceptibility is expected to be negligible in the test regions (Figs. 7 and 9), and possibly in other regions. We stress that the QNL threshold model does not rank the areas that were not classified as non-susceptible to landslides. This is different from the outcomes of landslide susceptibility models based on standard classification methods (Chung and Fabbri, 1999; Guzzetti et al., 1999, 2005a; Guzzetti, 2005).
Landslide susceptibility models that exploit classification methods (Chung and Fabbri, 1999; Guzzetti et al., 1999, 2005a) rank a study area based on the probability that a terrain mapping unit (e.g. a grid cell, slope unit, unique condition unit) pertains (or does not pertain) to the group of terrain units that have (or do not have) landslides (Guzzetti et al., 1999, 2005a). Where the probability of pertaining to the group of the unstable units is large, the mapping unit is considered susceptible to landslides. Conversely, where the probability of pertaining to the group of unstable units is reduced, the unit is considered non-susceptible to landslides. Conversely, when determining where landslides are 
not expected using a threshold-based modelling approach, like that proposed by Godt et al. (2012) for the conterminous United States, or our QNL model (see Sect. 3), only the nonsusceptible areas are outlined, and nothing can be said about the degree of susceptibility to landslides for the remaining territory.

This difference has an effect on the measurement of the performance of the threshold model. When measuring the predictive performance of threshold-based non-susceptibility landslide models, correct predictions are areas predicted as non-susceptible, where landslides were not observed (true positive - TP), and areas predicted as susceptible (i.e. not non-susceptible) where landslides were observed (true negative - TN). Incorrect predictions are areas predicted as nonsusceptible, where landslides were observed (FP), and areas predicted as susceptible (i.e. not non-susceptible), where landslides were not observed (FN). This is the opposite of what is most commonly done to evaluate the performance of landslide susceptibility models (Rossi et al., 2010).

Our work shows the importance of landslide information for the production of maps of non-susceptible landslide areas, and confirmed the importance of preparing accurate landslide inventory maps (Guzzetti et al., 2012). Where accurate landslide maps exist, the maps can be used to outline non-susceptible landslide areas in neighbouring and in distant areas. In a recent work, Günther et al. (2013) have pointed out that a complete coverage of landslide information is not available for Europe, and will not be available in the near future. They further argued that the lack of sufficient landslide information hampers the use of statistical approaches for the definition of continental-scale landslide susceptibility zonation. Our result opens the possibility of using statistical approaches for the synoptic-scale definition on non-susceptible landslide areas, provided accurate landslide information is available for a few areas. Determining the minimum amount and quality (Guzzetti et al., 2012) of the landslide information required for reliable statistical zonation of non-susceptible landslide areas remains an open problem.

Our model produced a geographical assessment of nonsusceptible landslide areas for very large regions (Figs. 7 and 9). The quality and geographical resolution of the terrain zonation depend on the quality and resolution of the terrain information used to calibrate and apply the model. The two morphometric variables used in this study were local terrain slope $S$ and regional relative relief $R$. It is known that the accuracy of morphometric derivatives of elevation data depends on the resolution of the DEM. Use of higher resolution DEMs (e.g. the $10 \mathrm{~m}$ resolution TINITALY/01 DEM of Italy (Tarquini et al., 2007, 2012)) would have probably increased the accuracy of the slope and, subordinately, of the relative relief measurements. A model of higher accuracy may have resulted in a smaller number of fatal landslide events in non-susceptible areas. However, use of the higher resolution DEM would not have allowed application of the model to the wider Mediterranean region (Fig. 9), for which the TINITALY/01 DEM is not available.

We stress that the synoptic-scale zonation, obtained by the QNL threshold model, cannot be used to ascertain the susceptibility (or the lack of susceptibility) of single sites. For this purpose, more accurate, site-specific analyses must be performed. In the non-susceptible areas, landslide susceptibility is expected to be negligible, i.e. a few landslides can be found in the non-susceptible areas. There are two reasons for this: firstly, the QNL was constructed to have $5 \%$ of the $(R, S)$ empirical data points representing landslide cells below the threshold model. Secondly, landslides that originate in susceptible areas can travel significant distances and reach non-susceptible areas. These landslides include, for example, rock falls, debris flows, and lateral spreads. In a few places, the proposed model outlined non-susceptible areas inside very large landslide deposits. Reasons for the (apparent) discrepancy include the fact that large, deep-seated landslides can produce significant areas of "flat" terrain in the depletion zone and in the toe area of the landslides, and that very large landslides are very old and partially dismantled by erosion and other landslides. We cannot exclude that the proposed model has failed to capture some instability condition locally.

Additional regional inventories, in Italy and elsewhere in Europe, should be used to refine the non-susceptibility threshold model proposed in this study. However, the quality of the inventories (Guzzetti et al., 2012), and specifically the accuracy and completeness of the landslide information, and the methods used to obtain the information from aerial photographs or in the field, and to transfer the information from the aerial photographs to the base maps and the digital databases, need to be considered before using the inventories to refine the non-susceptibility threshold model.

\section{Conclusions}

Exploiting accurate landslide information for 13 study areas in Italy, collectively covering $8.9 \%$ of Italy, and topographic information obtained from the SRTM DEM, version 2.1, we identified areas non-susceptible to landslides in Italy, i.e. areas in which landslide susceptibility is negligible, within a $5 \%$ error. In these areas, collectively covering $41.6 \%$ of Italy, landslides are expected to be negligible, i.e. rare (Fig. 7).

We used the map showing the areas expected to be nonsusceptible to landslides in Italy, and a map of the census zones to determine the location and the total number of people living in non-susceptible landslide areas. We found that $57.5 \%$ of the population of Italy (33.1 million people in 2001) live in non-susceptible areas, and the remaining $42.5 \%$ (24.5 million people in 2001) live in areas considered not to be non-susceptible to landslides. 
We extended the application of the non-susceptibility model for Italy to a $5.8 \times 10^{6} \mathrm{~km}^{2}$ area surrounding the Mediterranean Sea, and we tested the synoptic subdivision using independent landslide information for three areas in Spain. Results suggested that our model is capable of determining where landslide susceptibility is expected to be negligible in the Mediterranean region (Fig. 9).

We expect that our synoptic-scale zonation for Italy and for the landmasses surrounding the Mediterranean Sea will be used for insurance and reinsurance purposes (Godt et al., 2012), for small-scale land planning, and in operational landslide warning systems (Brunetti et al., 2009; Rossi et al., 2012) to outline the areas in which landslides are not expected, regardless of their trigger. For this purpose, we provide a specific WMS (see: http://geomorphology. irpi.cnr.it/tools/landslide-susceptibility-assessment/

non-susceptible-landslide-areas/). Use of the WMS will also help to validate the non-susceptibility threshold model with independent landslide information.

Acknowledgements. Work supported by the Italian Dipartimento della Protezione Civile - DPC, and by a grant of the Fondazione Assicurazioni Generali, Trieste. M. Alvioli was supported by a grant of the Regione Umbria, under contract POR-FESR Umbria 2007-2013, asse ii, attività al, azione 5, and by a grant of the DPC. We thank G. Herrera Garcia and R. M. Mateos (IGME) for making available landslide data for three study areas in Spain, and P. Salvati (CNR IRPI) for providing updated figures on the number of fatal landslides and of landslides fatalities in Italy in the period 1963-2012. We further acknowledge the two anonymous referees for their valuable comments, which helped us improve our work.

Edited by: T. Glade

Reviewed by: two anonymous referees

\section{References}

Antonini, G., Cardinali, M., Guzzetti, F., Reichenbach, P., and Sorrentino, A.: Carta Inventario dei Fenomeni Franosi della Regione Marche ed aree limitrofe, CNR Gruppo Nazionale per la Difesa dalle Catastrofi Idrogeologiche Publication no. 580, 2 sheets, scale $1: 100000$, GNDCI internal report, 1993.

Antonini, G., Ardizzone, F., Cardinali, M., Carrara, A., Detti, R., Galli, M., Guzzetti, F., Reichenbach, P., Sotera, M., and Tonelli, G.: Rapporto Finale, Convenzione fra il CNR, IRPI di Perugia e CSITE di Bologna, e la Regione Lombardia, Direzione Generale al Territorio ed Edilizia Residenziale, per lo sviluppo di tecniche e metodologie idonee alla produzione di carte della pericolositá e del rischio da frana in aree campione rappresentative del territorio della Regione Lombardia, unpublished report, 120 pp., 2000.

Antonini, G., Ardizzone, F. , Cacciano, M., Cardinali, M., Castellani, M., Galli M., Guzzetti, F., Reichenbach, P., and Salvati, P.: Rapporto Conclusivo, Protocollo di Intesa fra la Regione dell'Umbria, Direzione Politiche Territoriali Ambiente e Infrastrutture, ed il CNR IRPI di Perugia per l'acquisizione di nuove informazioni sui fenomeni franosi nella regione
dell'Umbria, la realizzazione di una nuova carta inventario dei movimenti franosi e dei siti colpiti da dissesto, l'individuazione e la perimetrazione delle aree a rischio da frana di particolare rilevanza, e l'aggiornamento delle stime sulla incidenza dei fenomeni di dissesto sul tessuto insediativo, infrastrutturale e produttivo regionale, unpublished report, 140 pp., 2002.

Ardizzone, F., Cardinali, M., Galli, M., Guzzetti, F., and Reichenbach, P.: Identification and mapping of recent rainfall-induced landslides using elevation data collected by airborne Lidar, Nat. Hazards Earth Syst. Sci., 7, 637-650, doi:10.5194/nhess-7-6372007, 2007.

Ardizzone, F., Basile, G., Cardinali, M., Casagli, N., Del Conte, S., Del Ventisette, C., Fiorucci, F., Garfagnoli, F., Gigli, G., Guzzetti, F., Iovine, G. G. R., Mondini, A. C., Moretti, S., Panebianco, M., Raspini, F., Reichenbach, P., Rossi, M., Tanteri, L., and Terranova, O.: Landslide inventory map for the Briga and the Giampilieri catchments, NE Sicily, Italy, J. Maps, 8, 176180, doi:10.1080/17445647.2012.694271, 2012.

Brabb, E. E.: Innovative approaches to landslide hazard and risk mapping, in: Proceedings of the 4th International Symposium on Landslides, Toronto, Canada, 30-32, 1984.

Brunetti, M. T., Peruccacci, S., Rossi, M., Guzzetti, F., Reichenbach, P., Ardizzone, F., Cardinali, M., Mondini, A. C., Salvati, P., and Tonelli, G.: A prototype system to forecast rainfall induced landslides in Italy, in: Proceedings of the First Italian Workshop on Landslides, Napoli, 2009.

Cardinali, M., Ardizzone, F., Galli, M., Guzzetti, F., and Reichenbach, P.: Landslides triggered by rapid snow melting: the December 1996-January 1997 event in Central Italy, in: Proceedings 1st Plinius Conference, Maratea, edited by: Claps, P. and Siccardi, F., Bios Publisher, Cosenza, 439-448, 2000.

Cardinali, M., Antonini, G., Reichenbach, P., and Guzzetti, F.: Photo-geological and landslide inventory map for the Upper Tiber River basin, CNR Gruppo Nazionale per la Difesa dalle Catastrofi Idrogeologiche Publication no. 2116, scale 1 : 100000 , GNDCI internal report, 2001.

Carrara, A., Cardinali, M., and Guzzetti, F.: Uncertainty in evaluating landslide hazard and risk, ITC J., 2, 172-183, 1992.

Chung, C.-J. F. and Fabbri, A. G.: Probabilistic Prediction Models for Landslide Hazard Mapping, ISPRS J. Photogramm. Remote S., 65, 1389-1399, 1999.

Chung, C.-J. F. and Fabbri, A. G.: Validation of spatial prediction models for landslide hazard mapping, Nat. Hazards, 30, 451472, 2003.

Cruden, D. M. and Varnes, D. J.: Landslide types and processes, in: Landslides, Investigation and Mitigation, Special Report 247, edited by: Turner, A. K. and Schuster, R. L., Transportation Research Board, Washington, D.C., 36-75, 1996.

De La Beaujardiere, J.: OGC Web Map Service Interface, version 1.3, 0. Open Geospatial Consortium, http://www.opengeospatial.org/standards/wms (last access: 26 August 2014), 2004.

Fabbri, A. G., Chung, C.-J. F., Cendrero, A., and Remondo, J.: Is Prediction of Future Landslides Possible with a GIS?, Nat. Hazards, 30, 487-503, 2003.

Farahmand, A. and AghaKouchak, A.: A satellite-based global landslide model, Nat. Hazards Earth Syst. Sci., 13, 1259-1267, doi:10.5194/nhess-13-1259-2013, 2013. 
Farr, T. G., Rosen, P. A., Caro, E., Crippen, R., Duren, R., Hensley, S., Kobrick, M., Paller, M., Rodriguez, E., Roth, L., Seal, D., Shaffer, S., Shimada, J., Umland, J., Werner, M., Oskin, M., Burbank, D., and Alsdorf, D.: The Shuttle Radar Topography Mission, Rev. Geophys., 45, RG2004, doi:10.1029/2005RG000183, 2007.

Galli, M., Ardizzone, F., Cardinali, M., Guzzetti, F., and Reichenbach, P.,: Comparing landslide inventory maps, Geomorphology, 94, 268-289, 2008.

Godt, J. W., Coe, J. A., Baum, R. L., Highland, L. M., Keaton, J. R., and Roth Jr., R. J.: Prototype landslide hazard map of the conterminous United states, in: Landslides and Engineered Slopes: Protecting Society through Improved Understanding, edited by: Eberhardt, E., Froese, C., Turner, K., and Leroueil, S., Taylor \& Francis Group, London, 2012.

Günther, A., Reichenbach, P., Malet, J. P., Van Den Eeckhaut, M., Hervás, J., Dashwood, C., and Guzzetti, F.: Tier-based approaches for landslide susceptibility assessment in Europe, Landslides, 10, 529-546, doi:10.1007/s10346-012-0349-1, 2013.

Günther, A., Van Den Eeckhaut, M., Reichenbach, P., Malet, J. P., Hervás, J.: Climate-physiographically differentiated PanEuropean landslide susceptibility assessment using spatial multicriteria evaluation and transnational landslide information, Geomorphology, 224, 69-85, doi:10.1016/j.geomorph.2014.07.011, 2014

Guzzetti, F.: Landslide Hazard and Risk Assessment, Ph.D. Thesis, Mathematich-Naturwissenschaftlichen Fakultat, Rheinischen Friedrich-Wilhelms-Universitat Bonn, Bonn, 389 pp., 2005.

Guzzetti, F. and Reichenbach, P.: Towards a definition of topographic divisions for Italy, Geomorphology, 11, 57-74, 1994.

Guzzetti, F., Carrara, A., Cardinali, M., and Reichenbach, P.: Landslide hazard evaluation: a review of current techniques and their application in a multi-scale study, Central Italy, Geomorphology, 31, 181-216, 1999.

Guzzetti, F., Cardinali, M., Reichenbach, P., Cipolla, F., Sebastiani, C., Galli, M., and Salvati, P.: Landslides triggered by the 23 November 2000 rainfall event in the Imperia Province, Western Liguria, Italy, Eng. Geol., 73, 229-245, 2004.

Guzzetti, F., Reichenbach, P., Cardinali, M., Galli, M., and Ardizzone, F.: Probabilistic landslide hazard assessment at the basin scale, Geomorphology, 72, 272-299, 2005a.

Guzzetti, F., Stark, C. P. and Salvati, P.: Evaluation of flood and landslide risk to the population of Italy, Environ. Manage., 36, 15-36, doi:10.1007/s00267-003-0257-1, 2005b.

Guzzetti, F., Galli, M., Reichenbach, P., Ardizzone, F., and Cardinali, M.: Landslide hazard assessment in the Collazzone area, Umbria, Central Italy, Nat. Hazards Earth Syst. Sci., 6, 115-131, doi:10.5194/nhess-6-115-2006, 2006.

Guzzetti, F., Ardizzone, F., Cardinali, M., Rossi, M., and Valigi, D.: Landslide volumes and landslide mobilization rates in Umbria, central Italy, Earth Planet. Sc. Lett., 279, 222-229, doi:10.1016/j.epsl.2009.01.005, 2009.

Guzzetti, F., Mondini, A. C., Cardinali, M., Fiorucci, F., Santangelo, M., and Chang, K.-T.: Landslide inventory maps: new tools for and old problem, Earth-Sci. Rev., 112, 42-66, doi:10.1016/j.earscirev.2012.02.001, 2012.

Hong, Y., Adler, R., and Huffman, G.: Use of satellite remote sensing data in the mapping of global landslide susceptibility, Nat. Hazards, 43, 245-256, 2007a.
Hong, Y., Adler, R., and Huffman, G.: An experimental global prediction system for rainfall-triggered landslides using satellite remote sensing and geospatial datasets, IEEE T. Geosci. Remote, 45, 1671-1680, 2007b.

Horn, B. K. P.: Hill Shading and the Reflectance Map, Proc. IEEE, 69, 14-47, 1981.

Jarvis, A., Reuter, H. I., Nelson, A., and Guevara, E.: Hole-filled seamless SRTM data V4, International Centre for Tropical Agriculture - CIAT, available at: http://srtm.csi.cgiar.org (last access: 26 August 2014), 2008.

Kirschbaum, D. B., Adler, R., Hong, Y., and Lerner-Lam, A.: Evaluation of a preliminary satellite-based landslide hazard algorithm using global landslide inventories, Nat. Hazards Earth Syst. Sci., 9, 673-686, doi:10.5194/nhess-9-673-2009, 2009.

Koenker, R. W.: Quantile Regression, Cambridge U. Press, Cambridge, 2005.

Nadim, F., Kjekstad, O., Peduzzi, P., Herold, C., and Jaedicke, C.: Global landslide and avalanche hotspots, Landslides, 3, 159-173, 2006.

Pike, R. J.: The geometric signature: Quantifying landslide-terrain types from digital elevation models, Math. Geol., 20, 491-511, doi:10.1007/BF00890333, 1988.

Rossi, M., Guzzetti, F., Reichenbach, P., Mondini, A. C., and Peruccacci, S.: Optimal landslide susceptibility zonation based on multiple forecasts, Geomorphology, 114, 129-142, doi:10.1016/j.geomorph.2009.06.020, 2010.

Rossi, M., Peruccacci, S., Brunetti, M. T., Marchesini, I., Luciani, S., Ardizzone, F., Balducci, V., Bianchi, C., Cardinali, M., Fiorucci, F., Mondini, A. C., Reichenbach, P., Salvati, P., Santangelo, M., Bartolini, D., Gariano, S. L., Palladino, M., Vessia, G., Viero, A., Antronico, L., Borselli, L., Deganutti, A. M., Iovine, G., Luino, F., Parise, M., Polemio, M., Tonelli, G., and Guzzetti, F.: SANF: National warning system for rainfall-induced landslides in Italy, in: Landslides and Engineered Slopes: Protecting Society through Improved Understanding, Vol. 2, edited by: Eberhardt, E., Froese, C., Turner, A. K., and Leroueil, S., CRC Press, Taylor \& Francis Group, London, 1895-1899, 2012.

Tarquini, S., Isola, I., Favalli, M., Mazzarini, F., Bisson, M., Pareschi, M. T., and Boschi, E.: TINITALY/01: a new Triangular Irregular Network of Italy, Ann. Geophys., 50, 407-425, 2007, http://www.ann-geophys.net/50/407/2007/.

Tarquini, S., Vinci, S., Favalli, M., Doumaz, F., Fornaciai, A., and Nannipieri, L.: Release of a 10-m-resolution DEM for the Italian territory: Comparison with global-coverage DEMs and anaglyph-mode exploration via the web, Comput. Geosci., 38, 168-170, 2012.

Trigila, A., Iadanza, C., and Spizzichino, D.: Quality assessment of the Italian Landslide Inventory using GIS processing, Landslides, 7, 455-470, doi:10.1007/s10346-010-0213-0, 2010.

Van Den Eeckhaut, M., Hervás, J., Jaedicke, C., Malet, J. P., Montanarella, L., and Nadim, F.: Statistical modelling of Europe-wide landslide susceptibility using limited landslide inventory data, Landslides, 9, 357-369, 2012.

Verdin, K. L., Godt, J., Funk, C., Pedreros, D., Worstell, B., and Verdin, J.: Development of a global slope dataset for estimation of landslide occurrence resulting from earthquakes, US Geological Survey Open-File Report 2007-1188, US Geological Survey, Reston, Virgina, 2007. 